\title{
Modelos para una Santa. El necesario icono en la vida de Teresa de Ávila
}

ANTONIO CEA GuTiÉRREZ Departamento de Antropología de España y América. CSIC. Madrid

a Teresa Álvarez Ruiz

\section{RESUMEN}

Desde el binomio imagen de culto y mundo devocional, se analiza el fenómeno de la espiritualidad personal, ya tridentino, en el espacio conventual femenino del siglo XVI. Bajo una perspectiva etnoliteraria y a través de los textos ascético-místicos de Teresa de Jesús y de su copiosa correspondencia epistolar, descubrimos el interior de esta extraordinaria mujer y su entorno social. En su lucha ascensional se debate la Santa entre la austeridad y el hedonismo, entre la privación y lo que le causa placer, entre el bien y el mal, teniendo al propio Cristo, a la Virgen y a los santos de su devoción como diana materializada en sus imágenes.

Palabras clave: Devoción, Imágenes de culto, Mundo femenino, España, Siglo XVI, Etnoliteratura.

\section{SUMMARY}

From the binomial consisting of cult images and devotional world, the author analyzes post-Tridentine personal spirituality in women's convents of the $16^{\text {th }}$ century. By looking into St. Theresa's ascetico-mystical texts and extensive epistolary correspondence from an ethnoliterary perspective, the analyst can unveil the inside of this extraordinary woman and her social context. In her struggle for spiritual ascension, the Saint oscillated between austerity and hedonism, between privation and pleasure-seeking, between good and evil, holding Jesus Himself, Mary and the saints of her devotion as materialized target in the images of her.

Key Words: Devotion, Cult Images, Women's World, Spain, Sixteenth Century, Ethnoliterature.

A través de la obra de Teresa de Ávila —-mujer excepcional, monja mística y reformadora del Carmelo- se analizan los conceptos de devoción e imagen de culto como vías de espiritualidad en tiempos de la Contrarreforma. Se destaca, además, la importancia del documento literario, desvelador de 
las costumbres religiosas de esa época. Para Teresa de Jesús la devoción es un efecto edificante, causado en el alma ejercitada para recibir esa benéfica impronta por personas, cosas o situaciones, provocando el vertiginoso vuelo del éxtasis a pesar del demonio estorbador. Las imágenes de devoción, en cambio, son acertado retrato donde se oculta el amado divino y por ello, asidero corporal para el alma que lo busca, y necesaria mercancía en el mundo de la religiosidad y del arte. Lo concreto y objetual es motor de la espiritualidad ascético-mística en el doble ámbito en que se mueve la personalidad de esta extraordinaria mujer: el mundo de lo cotidiano, con el empeño de sus fundaciones, y el elevado negocio de su alma, a través de las devociones que sirven a la santa como scala caeli.

Ambos conceptos (devoción e imagen) mantienen una presencia constante en su obra, tanto la parte que refleja la huella de una mujer con los pies en tierra (Epistolario), como la del deseo de trascendentalidad (las Moradas, o el Libro de la Vida). Curiosamente y para ejercitar la introspección en sus "palomares" y ermitas carmelitanas sigue Teresa el icono hedonista y oriental del hortus conclussus: vistas con naturaleza arbolada y presencia de murmullo de agua, al mismo tiempo que figuras devotas moviendo a sus monjas a perfección. En su obra nos desvela cómo, a veces, por la afición a su hermosura no acierta a desprenderse de una imagen reteniéndola cuanto puede, casi contra su voluntad. Se muestra experta en calidades y precios adquiriendo pinturas en obradores toledanos para sus monjas de Sevilla, o comprando en ocasiones tallas y pinturas de las escuelas castellana y andaluza sin escatimar en los cuidados de embalaje y transporte. Señala las diferencias entre la pieza tallada o "de gracia" y la "vestidera" y defiende la capacidad de perfección de las estampas seriadas. Siempre está dispuesta la santa fundadora a regalar y a recibir una imagen galana, junto con mermeladas o curativos remedios, sirviéndose de ella como trampantojo en el caso de la virgen-priora en el coro de la Encarnación de Ávila. También le ayudan para aumento de la devoción las arquitecturas efímeras como impronta de belleza en las tomas de posesión de las fundaciones de Sevilla y Medina. A veces, el ingenio y santidad de sus freilas pone a la devoción de estas hechuras lo que les falta en calidad, en representaciones de Navidad y recreos por medio de agudas invenciones, dichas, cantadas o teatralizadas. Igualmente, subrayar cómo la extremada hermosura de una imagen, traída de Flandes llega a ser la causa natural de la fundación de un convento, como en el caso del de Duruelo en Salamanca; imágenes y devociones que utiliza la santa andariega para iniciar su particular vuelo.

La santa de Ávila fue siempre amiga de imágenes, aferrándose a ellas por necesidad en una etapa en la que se veía poco iniciada en la oración, supliendo así su escasa aptitud para la abstracción interior; quizá también 
por la sequedad espiritual a pesar del alma, lo que en ascética se denomina tribulación, como si se le escondiera el amado:

Tenía tan poca habilidad para con el entendimiento representar cosas, que si no era lo que vía, no me aprovechava nada de mi imaginación, como hacen otras personas que pueden hacer representaciones a donde se recogen. Yo sólo podía pensar en Cristo como hombre, más es ansí que jamás le pude representar en mi — por más que leía su hermosura y vía imágines - sino como quien está ciego y a oscuras [...]; a esta causa era tan amiga de imágines (Libro de la Vida: 9,6).

Incapaz de desasirse de la representación humana de Cristo y sin poder cerrar los ojos, leía su hermosura a través de la de las imágenes cuya perfección causa deleite, despierta la ausente presencia, provoca amor y, a veces, se convierte en desatada amalgatofilia hacia la imago vivens. Se cuestiona la santa si es capaz la imaginación de recomponer la hermosura humana de Cristo con la perfección anatómica, por muy ordenada que vaya. No puede, se contesta, porque no nos es dado imaginar lo que aporta de nuevo a la belleza corporal un cuerpo glorioso resucitado. La correcta impresión de la figura de Cristo se esculpe en el entendimiento y permanece rigurosa a los ojos del alma que está en gracia como espejo de Dios. Aún siendo Teresa tan defensora de la calidad de las imágenes justifica la hechura y la reverenciabilidad de las más torpes por lo que representan, con tal que conserven el decoro ${ }^{1}$. Sobre las trazas y retratos de Cristo, "que hartos los he visto buenos" afirma:

es disbarate pensar que tiene semejanza lo uno con lo otro en ninguna manera, no más ni menos que la tiene una persona viva a su retrato, que por bien que esté sacado no puede ser tan al natural, que —en fin — se ve es cosa muerta [...] Que hay la diferencia que de lo vivo a lo pintado, no más ni menos (Libro de la Vida: 28,7 y 29,1$)^{2}$.

También es consciente de aquellos elementos accesorios "muchas molduras y cosas curiosas", contrarios al ambiente ascético que pretende en sus monjas y 'palomares', apreciando cualquier alimento que despierte el amor a Dios, pues al alma no sólo sirven las imágenes sino también pulirlas ${ }^{3}$. Valora

${ }^{1}$ Concepto tan tenido en cuenta por las rúbricas eclesiásticas como se aprecia en los mandatos de Santa Visita, a través de los libros de Fábrica parroquiales. Se entiende por decorosa la imagen cuidada a la que no falta ninguno de sus elementos y en buen estado de conservación, lejos del concepto de la antiquitas de la belleza de la ruina.

${ }^{2}$ La cursiva es mía para subrayar el refrán del que echa mano la santa y que trae en su Vocabulario Correas, añadiendo éste el siguiente comentario: "Cuando hay gran diferencia en algo".

3 Pulir en su época se utiliza en general por adornar. (Ver Cea 2000: 129-138). 
la conveniencia del adorno como santo entretenimiento y la importancia del ornato, puesta de relieve en la toma de posesión solemne de sus conventos, y la sabia impronta de la belleza como arte efímero. Teresa, buena conocedora del arte conventual de su tiempo, encarga crucifijos pintados en Toledo para sus monjas de Sevilla y grabados sevillanos de calidad para las de Castilla, o tallas de Burgos y de Madrid. Se perfila como acopiadora y proveedora en el mercado de la imaginería y de la estampa, géneros que en ocasiones da o recibe como fineza de sus benefactores. Sabe bien distinguir entre la iconografía más tradicional, por ejemplo la de la Trinidad "Como se pinta" (De Pamplona 1970) y las fórmulas de novedad, vinculando el poder de la oración mental a la imagen de la Pasión o paso, lo que requiere un aprendizaje familiar desde la niñez — trasmitido por la madre a los

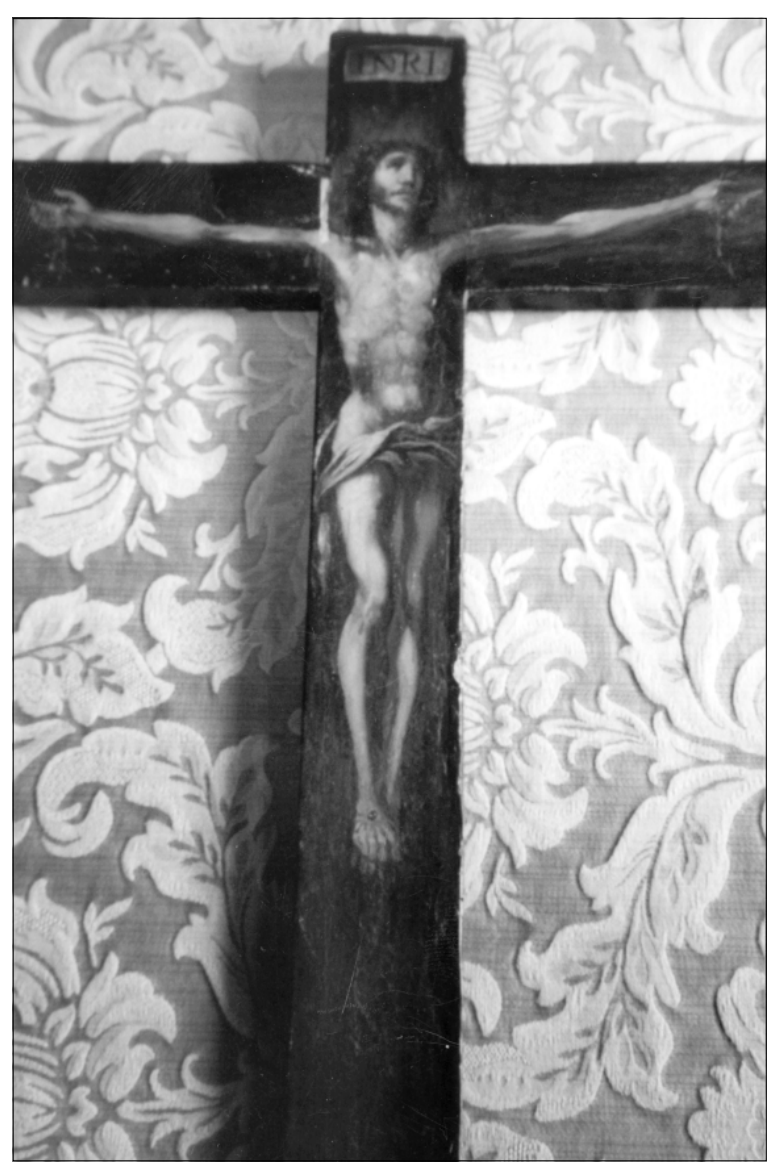

FIGURA 1: Crucifijo toledano pintado, ss. XVI-XVII (col. part., foto J. M. Castaño) hijos o por la abuela a los nietos - hasta llegar a la compasión y lágrimas en los tormentos de Cristo. Esta provocada satisfacción dolorosa con imágenes "muy a lo vivo" y devotas — de Cristo, la Virgen y los santos-, halla a veces en ellas respuestas humanizadas. Pero la imagen real, o visionaria no sólo supone para Teresa de Jesús el pricipium boni, también el del mal que causa el demonio, al que califica de gran pintor engañador. Se trata de la representación falsa que toma forma de carne, pero que no se debe contrahacer con aquella que viene de Dios. La realidad no debe ser suplida por su retrato (Camino de Perfección: 61,6) abandonando la presencia viva 
por mirar al dibujo. Sólo cuando la 'mariposilla' se quema en el fuego divino, esto en las séptimas moradas, es ya innecesaria la imagen.

La producción de esta mujer extraordinaria, desde los pasajes supremos en su obra mística hasta las necesidades más humanas de la cotidianidad religiosa y social que traslucen sus cartas, muestra la generosa cosecha en el campo de la antropología cultural y de lo interdisciplinar desde una lectura liberada de exclusivos intereses literarios y espiritualistas.

Podemos señalar en sus textos tres diferencias sobre la imagen: el icono propiamente dicho o la imagen como tal; las imágenes descritas en sus visiones y, por último, el panteón iconográfico tradicional a través de las fórmulas oracionales. Las limitaciones de espacio nos impiden tratar pormenorizadamente todos estos aspectos y ejemplos. No obstante, para una mejor comprensión de la totalidad de este estudio estimamos necesario apuntarlos aquí, aunque sea de forma muy somera y sintética:

\section{A) El icono real o la imagen propiamente dicha}

Al referirse a las imágenes describe Santa Teresa su calidad, lindeza, proporción y tamaño, procedencia y destino, estima, apego, etc., pero elude el retrato formal de la pieza para imaginarla sin verla y la advocación particular con sus atributos. Es en los pasajes visionarios, en cambio, donde relata con todo detalle los pormenores iconográficos, ademanes, colores y gestualidad.

- Tipología y variantes:

- Imágenes vestidas de gracia e imágenes vestideras.

- Cruces pintadas y otras pinturas en tabla y en lienzo.

- Grabados o estampas y dibujos.

- Relicarios de pie, joyas-relicario y otros amuletos.

- Embalaje, envoltorio y transporte de las imágenes.

- Escuela y procedencia:

- Toledo, Valladolid, Burgos, Sevilla, Madrid, Flandes, Quito, otras.

- Uso de la imágenes:

- Retablos, celdas, ermitas, el propio cuerpo, otros.

B) La imagen representada en visiones.

- La visión. Tipología y grados:

- Visión imaginativa; intelectual; auditiva; arrobamiento; visión con los ojos del alma; visión con los ojos del cuerpo; percepción sin imagen; representación falsa. 
- Situación y temporalidad:

- Ermita; celda; oratorio; coro; altar (la ermita en los huertos del Carmelo es óptima plataforma para el vuelo del alma a la visión).

- Día y hora.

- Duración: lo que dura un relámpago; un ave maría; una salve; una hora; dos horas y media; otros.

- Formulación:

- "Vi"; "me dió un recogimiento"; "casi que se me dió a ver"; otras.

- Manifestación corporal y consecuencias (estado en que recibe la visión y cómo queda luego).

- Los caminos que provocan la visión:

- Técnicas de oración vocal y mental con la ayuda de imágenes devotas.

- Meditaciones; oraciones; sermones; canciones; recreaciones; otras.

- Iconografía:

- Visiones sobre la Trinidad y con el Espíritu Santo "Como lo pintan".

- De la vida de Cristo, en especial la Pasión y la Resurrección.

- De la vida de María.

- Sobre los santos.

- Visiones ad superos: el cielo; los grados de gloria; el trono de Dios y la majestad divina; Dios como un diamante.

- Visiones ad inferos: el purgatorio y el infierno.

- Visiones del diablo.

- La militia mundi: el mundo en batalla contra el alma; visión de la Compañía de Jesús, otras.

- Visiones sobre difuntos como subgénero literario.

Puede haber visiones en que la realidad o representación de la imagen se ajusta a alguna conocida y concreta, en otras se aparta de ella y en otras no le recuerda ninguna.

\section{C) La imagen rezada.}

Para esta iniciación en la oración mental y vocal hay un primer aprendizaje familiar y doméstico durante la infancia, hacia los siete años: «los hacía entrar a tiempos en un oratorio"; "a pasos y descanso". En los conventos cada día de la semana se ordena la oración por un calendario sobre la Pasión de Cristo popularmente conocida con los nombre siguientes: Vexilla Regis; los tormentos; las arma Christi; los improperios; los estigmas; las suertes de la Pasión (denominación que utiliza la santa). 
Devociones o nombres de oraciones cuya iconografía nombra Santa Teresa:

- A la limpieza de nuestra Señora; a la pobreza de Cristo; a las angustias de María; a las tres horas de Cristo en la cruz; a las ciento y tantas suertes de la Pasión; "lo que no está escrito" sobre las veces que sangró Cristo (Ortiz, 2000: 175-176). Para este estudio sobre la iconografía en Teresa de Ávila que planteamos en clave de glosa, analizando los textos desde una perspectiva etno-artística, nos detendremos sólo en tres aspectos fundamentales: las imágenes relacionadas con su propia biografía, como un retablillo devocional de piezas concretas que ella disfruta; Santa Teresa y el gusto por la estampa y, por último, la imagen del demonio en la percepción de sus tentaciones ${ }^{4}$.

\section{LAS IMÁGENES RELIGIOSAS QUE CITA LA SANTA EN SU VIDA}

1. El teatro conventual: capillitas, escaparates o conventinos, figurillas $y$ nacimientos e invenciones (el caso de Bela Dantisco)

Los dos pasajes en que se refiere la santa a Isabelita Dantisco, hermana pequeña del Padre Gracián ${ }^{5}$, expresan con claridad cómo debieron ser los recreos y representaciones conventuales en esta época, en especial en tiempo de Navidad, que comprenden y requieren los siguientes elementos e ingredientes: Ingenuidad, gracia natural e imaginación, habilidad y destreza para poder suplir la pobreza de recursos con que se contaba: unos "pastorcillos malaventurados", "monjillas" e imagen de Nuestra Señora, figuras y hechuras que se combinan y completan con invenciones de coplas y villancicos acompañados de elementales instrumentos, ramos, pastoradas, loas y comedias de santos. Improvisaciones, que a veces arropan temas tradicionales heredados, con argumentos para cada momento y fiesta (Cea 2002: 55106). Estas invenciones comprenden dos vertientes: una, personal y privada, que se ejercita de contino en los tiempos de recogimiento individual — cada monja en su ermita o capillita-, con dos o tres figuras (en este caso un Niño Jesús y pastores) recreando pasos de la Natividad ¿Se incluye la propia Dantisco, además, en el papel de pastora, partera o madre-virgen? El resultado es el arrobamiento. Esta actividad y actitud teatral alternaba a diario con el conocimiento y ejercicio de labores manuales para el abastecimiento y necesidades de la propia comunidad y para satisfacer los encargos

${ }^{4}$ Cito por la edición de Efrén de la Madre de Dios y Steggink, 4ª 1974.

5 Carta 166 a Gracián y Carta 161 a María de San José. 
externos y obligaciones o cumplimientos con los benefactores. "Cuando no es hora de recreación está en su ermita, tan embevida en su Niño Jesús y sus pastores y su labor que es para alabar a Dios" ${ }^{6}$.

Además de esta actitud privada está la manifestación de todo lo anterior en público, donde participa activa o pasivamente la comunidad durante los recreos, improvisándose coplas y coros ante la priora en fiestas señaladas. Esto es también resultado, además de la educación familiar como dote, de la instrucción y adoctrinamiento conventual de las que entran niñas y que luego acabarán siendo profesas, o saldrán para desposarse. En un pasaje delicioso compara la santa a dos de estas niñas internas y sus cualidades: la gracia natural de su sobrina Teresilla y la de la tal Bela Dantisco para las invenciones:

Es extraña la habilidad de esta criatura, que con unos pastorcillos malaventurados y una monjillas y una imagen de Nuestra Señora que tiene, no viene fiesta que no hace invinción de ello, en su ermita u en la recreación, con alguna copla a que ella da tan buen tono y la hace que nos tiene espantados?

Se trata, en efecto, de una verdadera animación con unas figuras pobres y desvencijadas, carencias que se suplen con gestos y canciones. Estamos de pleno ante un caso de verdadero teatro religioso popular.

\section{DEVOTOS ENAMORADOS DE IMÁGENES}

\section{La Virgen madrileña que enamoró al Padre Juan Roca}

Estando muchacho en Madrid iva muchas veces a una imagen de Nuestra Señora que él tenía mucha devoción —no me acuerdo a dónde era—; llamávala su enamorada, y era muy ordinario lo que la visitaba [...]. Dice que algunas veces le parecía tenía [...] la imagen hinchados los ojos de llorar por las muchas ofensas que se hacían a su hijo (Fundaciones: 23,5).

Se trata de un caso patente de amalgatofilia con algunas connotaciones particulares que se desprenden del texto: Amor desigual en edad de pederastia con frecuencia de visitas en régimen de cortejo. Se perfila Juan Roca con actitudes de enamorado, entre ellas la del apelativo personal sobre el de pila que da a la imagen: "su enamorada". Quizá por esta razón no recuerda Santa Teresa la advocación, porque nunca la llamara por su verdadero nombre, ni la ubicación. Olvidos que, además, no serían de extrañar con tan innumerable población de advocaciones en la Corte. La ima-

${ }^{6}$ Carta 166, diciembre de 1576 a Gracián desde Toledo.

7 Carta 171 desde Toledo, en 9 de enero de 1577 a Gracián. 
gen le parece humanizada y con volubilidad en el estado de ánimo, como una mujer de carne y hueso y con reacción de llorona por los pecados (Jular 1999: 103-128 y Cea 1996: 57-127).

\title{
2. La Virgen de Mancera de Abajo (Salamanca) aficiona el verla
}

\section{Dice la santa:}

\begin{abstract}
Venían allí a confesar algunos cavalleros que estavan en aquellos lugares [...]. Entre estos fue don Luis [Toledo] señor de las Cinco Villas. Este cavallero havía hecho una iglesia para una imagen de Nuestra Señora, cierto bien digna de poner en veneración. Su padre la envió desde Flandes a su agüela o madre (que no me acuerdo cuál) con un mercader. El se aficionó tanto a ella que la tuvo muchos años, y después a la hora de muerte mandó se la llevasen. Es un retablo grande, que yo no he visto en mi vida (y otras personas dicen lo mesmo) cosa mejor. El padre Fray Juan Antonio de Jesús, como fue a aquel lugar a petición de este cavallero y vio la imagen, aficionóse tanto a ella —y con mucha razón- que aceptó de pasar allí el monasterio, llámase este lugar Mancera [de Abajo] a una legua de Duruelo; labróles este cavallero un monesterio conforme a su profesión, pequeño y dió ornamentos, hízolo muy bien (Fundaciones: 14,9).
\end{abstract}

Se trata de un ejemplo de mercaduría religiosa, en este caso con la fama de que gozaba la de Flandes, cuya imagen por su belleza se despierta y despierta devoción como para pasar de reclamo personal doméstico y regalo familiar a blasón devocional y culto público en un templo9. La virtud de esta talla es la de una figura de mujer que aficiona con su hermosura —no parece que tenga actitudes humanizadas más que su quieta belleza de mujer - y anula la voluntad arrastrándola inevitablemente hacia $s^{1}{ }^{10}$. Se aficiona primero el nieto del donante y comprador, quien la aparta de la compañía de su bisabuela (como en el rapto de la doncella) y la mantiene junto así hasta la hora de la muerte queriendo dejar a su amada en buena posición. Es pues un amor exhibido en un espacio público y no para gozar de él en sus estancias particulares. No queda determinado en qué momento "mandó se la llevasen". Hasta tal punto se aficiona a ella el carmeli-

8 Sobre el prodigio del estado de ánimo cambiante en una imagen, viví cuando niño uno en el caso de la Virgen de las Nieves de Póo de Llanes (Asturias). Los fieles la veían reir y llorar, hasta que descubrieron ser efecto del sol sobre las hojas de un árbol en una ventana cercana.

9 Sobre el fenómeno de la devoción "dormida" y "despierta" (Vid Cea, 1992: 153).

${ }^{10}$ En Autoridades, "aficionar" como 1aㅗ acepción es " ganar la voluntad de otro con su hermosura [...] atrahiendo así las personas con quien trata. Dícese también y se extiende a las cosas inanimadas, que agradan a la vista". En Covarrubias, "aficionarse" es "enamorarse y acodiciarse". 
ta Fray Antonio de Jesús que será causa del traslado del monasterio de Duruelo a Mancera.

Si transferimos la voz "afición" a términos de esponsales, en el primer ejemplo obliga a retener la imagen como en secuestro, donándole en arras una casa. En el caso del fraile el nuevo esposo pasa su morada a la de la viuda.

Aparte del tema del enamoramiento, queremos subrayar la fórmula de ponderación que emplea Teresa para esta imagen. En primer lugar la expresión del impacto estético, muy digna de tener en cuenta viniendo de una mujer que, aunque se considere lega, es conocedora de los grandes centros comerciales del arte de su tiempo como Burgos, Toledo, Sevilla, Valladolid o Salamanca. En segundo lugar, porque apoya su criterio estético en el de otras personas a las que admira por su formación cultural.

\section{La imagen de Nuestra Señora que regala don Juan de Albornoz provoca placer el mirarla}

En tres ocasiones, con diferencia de siete años, relata la santa la personal historia de esta imagen. En carta desde Valladolid en 28 de diciembre de 1568 a doña Inés Nieto, residente en Madrid y esposa del donante, amigo íntimo del Duque de Alba comenta:

Pague Nuestro Señor a su merced la imagen. Bien me la deve. Suplico a vuesa merced me la tenga muy guardada hasta que yo la pida que será cuando tenga más asiento en algún monesterio que agora para gozarla.

No se corta Teresa en emplear el carnal verbo y la expresión sexual, "gozarla", al describir la imagen como objeto de placer y no solo como devoción. Verbaliza un deseo que pospone en espera de sosiego y circunstancias propicias para su disfrute — cuando esté más de quieto- en un lugar, lo que indica un carácter de secundariedad. Es además súplica de buen y seguro depósito y excusa para no dejarla en ningún convento al que no se sienta afectivamente vinculada.

Viniendo la imagen de parte de un personaje tan noble hace suponer que la pieza era de buena escuela y hechura. Con el "bien me la debe" demuestra la santa lo pagada que la tiene en oraciones por el benefactor (trueque el más socorrido entre las monjas), convertido así en deudor.

En la segunda carta, desde Sevilla con fecha de 19 de junio de 1575, a doña Inés, ya viuda, le recuerda lo siguiente:

no tengo olvidada la merced que vuesa merced me ha hecho de la imagen de Nuestra Señora (que será muy buena, pues al señor Albornos le contentó) y ansí 
suplico a vuesa merced la mande dar a quien el padre maestro Gracián enviare por ella, que su reverencia se encargará de enviármela a recaudo.

Se resalta aquí de nuevo el concepto de alta calidad, afirmación implícita según una antigua opinión — probablemente a través de una carta que no se conserva- del donante Albornoz. La entrega, siete años pospuesta, (¿los que ella ha tardado en aposentar?) se dispone a través de un mediador muy particular y creo que esto no se debe a recelos sobre la seguridad de la imagen, ni a exclusivas razones de obediencia. Parece haber otras compartidas que incluyen la de esta placentera escultura.

En la tercera y última carta, cuatro meses después (Sevilla, 31 de octubre) y ya en posesión de la talla, le comenta la santa a doña Inés Nieto: "Mientras más miro la imagen, más linda me parece, y la corona muy graciosa. Conmigo me la pienso llevar si torno para allá» (Cartas 17, 82 y 91).

Los conceptos que aplica en este pasaje van muy con el contexto de la época y con su condición de mujer y de monja. La imagen se vuelve "más linda" cuando se la remira —el cariño que provoca el roce- y aparece dotada de las cualidades armoniosas de proporción y conservación. Se añade, además, el calificativo de "muy graciosa" para la corona que guarnece su cabeza. Así no sólo elogia la estructura de la imagen, también es expresiva con los motivos ornamentales como éste de la corona, lo que parece añadir algo de extrínseca belleza a la ya de por sí hermosa figura. Por el contexto podría adscribirse esta pieza a la escuela de Valladolid y se percibe como que pasa a formar parte de los enseres personales de la santa ${ }^{11}$.

\section{La Virgen ¿toledana? que envía la de Ávila a las de Caravaca}

En carta a la sevillana madre María de San José , tantas veces confidente, comenta Santa Teresa desde Toledo ${ }^{12}$ : "Ahora he de enviar a Caravaca una imagen de Nuestra Señora que les tengo, harto buena y grande, no vestida y un San Josef me están haciendo: y no les ha de costar nada ${ }^{13}$.

11 Aunque el calificativo de "lindo" que aplica la santa a la imagen podría parecer hoy una manera femenina de lenguaje, no lo era en su tiempo. Pero sí se reconoce, en cambio, que los adjetivos que expresan intensidad en cualidad física y los valorativos, en este caso, "más linda" y "muy graciosa", suelen pertenecer más al lenguaje de la mujer. (Ver en Otte 1988. También en Krüger 1960).

12 Carta 194, con fecha 7 de noviembre de 1576.

13 Seguramente la talla de San José se hace por expreso encargo de la santa, lo que parece indicar la aún incipiente demanda de esta devoción (quizá no había en qué escoger en el taller) que Teresa promocionará definitivamente. 


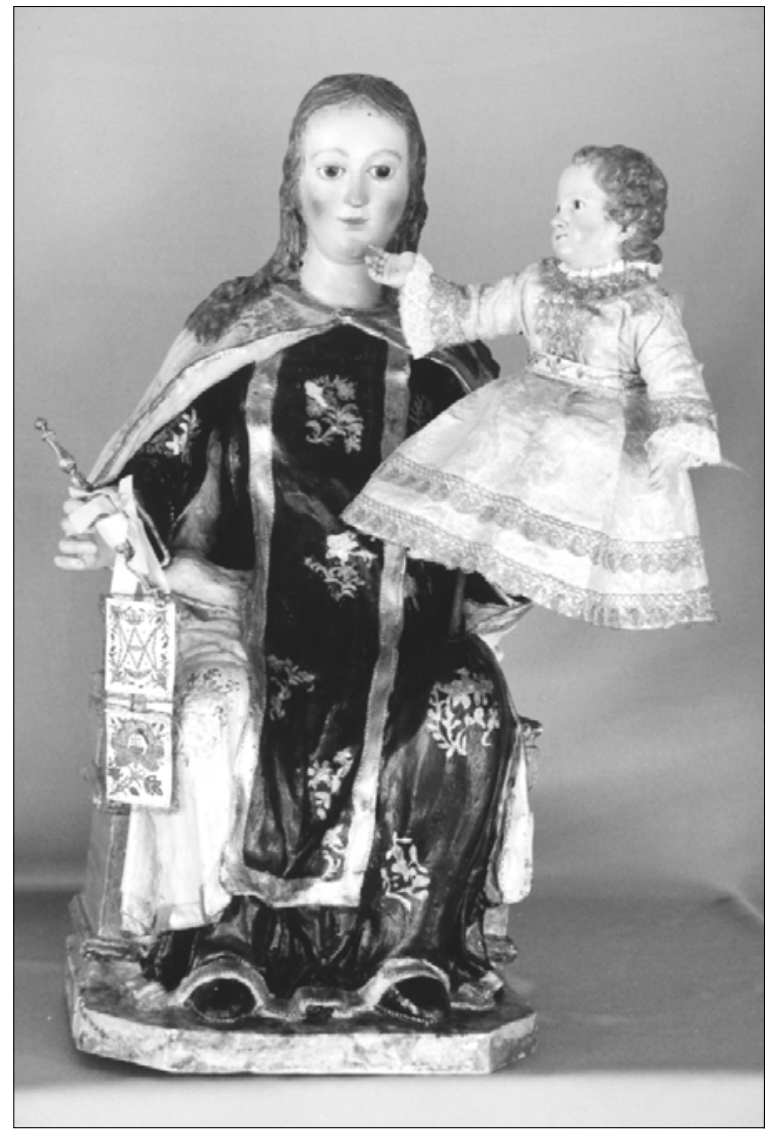

FIgura 2: Virgen del Carmen, regalo de Santa Teresa a las Carmelitas de Caravaca. (Cortesía de Vicente Redondo).
Consideramos este pasaje, y el que viene, de trascendental importancia para el estudio de la iconografía de la época por su aquilatada clasificación técnica: describiendo la imagen de $N^{a} S^{\underline{a}}$ como buena en calidad y tamaño, dentro de las de tipología conocida como "no vestidera" (el Niño sí), o sea, de las denominadas "vestidas de gracia" (Ver en Cea 1992: 37-47). Parece que tenía esta escultura como joya en reserva de gran acontecimiento. Demuestra, además, alta estima hacia la fundación y monjas de Caravaca a lo que se suma el encargo toledano de un San José; ambas imágenes para consuelo de aquellas monjas que extrañaban

su tierra. Llegamos a preguntarnos si se estaba despegando la santa de esta imagen, regalo de Albornoz.

Un mes después escribe a Diego Ortiz ${ }^{14}$ mostrándole la alegría por la llegada del San José y encargando con urgencia un embalaje seguro para su transporte a Caravaca:

Harto consuelo me ha dado la venida de mi padre San Josef tan presto y de que sea vuesa merced tan su devoto ${ }^{15}$. Por caridad, vuesa merced me la haga de

${ }^{14}$ Carta 159 desde Toledo y a Toledo con fecha de 16 de diciembre de 1576.

${ }^{15}$ La costumbre social y piadosa, especialmente entre mujeres, de verbalizar en conversación abierta los gustos por devociones personales, como quien expresa cualquier tendencia cotidiana, pervivió en España, creo, hasta el concilio Vaticano II. Esta ausencia de pudor llamaba poderosamente mi atención cuando, siendo yo niño y de la mano 
mandarle tomar la medida de ancho y largo, havía de ser luego, porque se haga mañana la caja y que el martes no podrán por ser fiesta y el miércoles de mañana se van los carros. Y no hago poco en dar tan presto la imagen de $N^{a} S^{a}$, que me deja grandísima soledad; por eso vuesa merced remedie con la que me ha de dar, para la Pascua, por caridad.

Cuesta entender en una mujer de tan alta comunicación con Dios su apego a las imágenes hasta llegar a sentir pozos por su ausencia ${ }^{16}$. Esta afecciones seguramente hubieran tenido su penitencia, de haberse manifestado en confesión, a pesar de que esperaba el regalo de una nueva en los próximos días. El pago, según se anticipa a señalar la santa, vendrá en forma de aguinaldo ${ }^{17}$ que Dios otorgará al bienhechor:

el aguinaldo pediremos de buena gana a nuestro señor para vuesa merced y esos

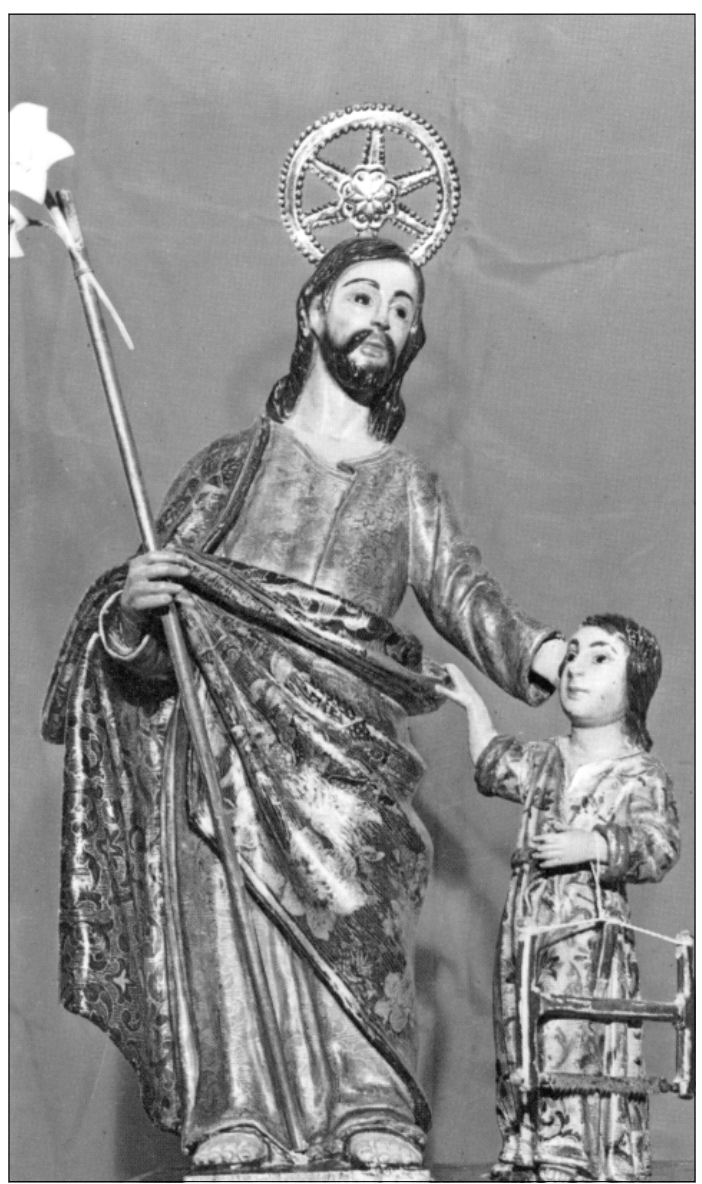

Figura 3: Imagen de San José para las Descalzas de Caravaca de la Cruz. (Cortesía de Vicente Redondo). señores [¿el entallador y los donantes?]. Hacen las tres fundadoras [Francisca de San José, Francisca de la Cruz y Francisca de la Madre de Dios] el día de año nuevo profesiones y le será consuelo tener allá las imágenes.

de mi madre, escuchaba semejantes conversaciones en la calle sobre la abogacía y poder de milagros de tal o cual santo.

16 Término griego que denota deseo, ansia, añoranza y pérdida.

${ }^{17}$ La costumbre de dar los aguinaldos (cantados o rezados) como forma petitoria tradicional es aquí un recurso de monja para descargar la deuda contraida con el donante en Dios, con Teresa en el papel de protagonista cantora. 
Parece desprenderse con claridad de estos pasajes la dependencia en los conventos de sus benefactores, hasta para las imágenes titulares de altar, ello parece venir a confirmar la escasa o nula dote de las monjas, al menos en esta Orden.

La espléndida descripción del embalaje del San José aporta además unos detalles que generalmente se omiten por supuestos en las cartas de obligación. Una vez más se resalta la idea del consuelo espiritual y físico con la presencia de las imágenes y al contrario: la tristeza que produce su ausencia.

\section{IMÁGENES CON ACTITUDES Y RESPUESTAS HUMANIZADAS}

\section{Teresa prohijada por una imagen}

Acuérdome que cuando murió mi madre, quedé yo de edad de doce años, poco menos. Como yo comencé a entender lo que avía perdido, afligida fuime a una imagen de Nuestra Señora y supliquele fuese mi madre con muchas lágrimas. Paréceme que aunque se hizo con simpleza, que me ha valido; porque conocidamente he hallado a esta Virgen soberana en cuanto me he encomendado a Ella y, en fin, me ha tornado a sí (Libro de la Vida: 1,7$)^{18}$.

La imagen co-protagonista de este entrañable pasaje debía hallarse en alguna iglesia o convento de la ciudad de Ávila, frecuentado ya de niña por la santa, cuya ubicación y nombre se reserva para no desvelar el pacto secreto entrambas — devota e imagen - con la que fija parentesco. El trato entre la talla y la niña implica gestualidad unilateral, la de Teresita, pero con reacción de causa-efecto y humanización internalizada. El ritual de la niña que se formalizó y se expresó con dichos, gestos y lágrimas, fue

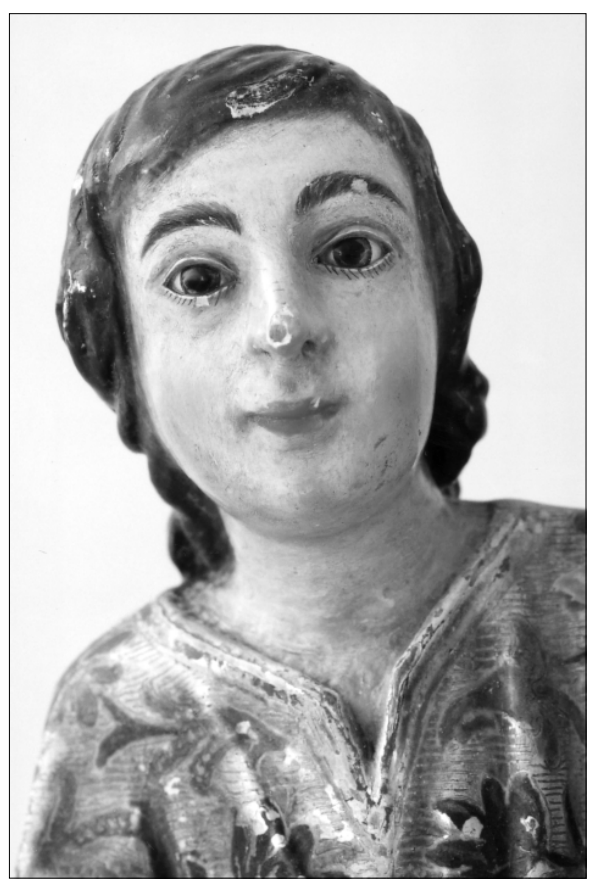

Figura 4: Niño Jesús del San José enviado a la Fundación de Caravaca, detalle (Foto Mimosa).

18 Este pasaje parece deudor del que trae Berceo en el caso de la abadesa preñada -III- 21, verso 515: "y tenié la imagen de la Sancta Reína [...], ca por todos en cabo éssa fue su madrina". Cito por la edición de Dutton (1971: 161). 
silenciosamente atendido por la imagen y correspondido de por vida. Teresa se estaba "acogiendo al manto" y "metiéndose por la manga"19.

\section{La imagen de la Virgen que hace de priora + la descensión de la Virgen verdadera}

El pasaje de la descensión de María al coro de la Encarnación de Ávila, ocupando el asiento y papel de priora y rodeada de ángeles que se posan en los brazales y misericordias, es la respuesta con carácter de mirabilis al gesto humanizante de colocar la imagen de la Virgen en el lugar que le pertenecía a Teresa y supliendo, por tanto, su responsabilidades. Este trampantojo a lo divino y superposición de la visión intelectual + representación figurada responde a la iconografía del bene dixisti de me o bene scripsisti de me. María, en recompensa, obra el milagro de la sustitución, tipo literario recogido ya en la literatura medieval ${ }^{20}$. El subtipo en este caso es que todo el monasterio conoce que hay dos prioras: Teresa y la Virgen, llamada de la Clemencia. Existen además paralelismos entre la visión, que la santa califica de intelectual, y la pintura, regalo de la condesa de Osorno ¿Se trata pues de una fusión superpuesta de carácter maravilloso? Se verbaliza el desdoblamiento entre la Virgen real de la visión y la imagen: "Bien acertaste en ponerme aquí", también el trueque, haciendo el papel de priora y valedora ante Cristo de las oraciones del convento. Más rara resulta la participación con palabras del Padre Eterno, que es quien pide favor por favor. La talla de Nuestra Señora interpreta aquí un sobrepapel —el de madre y el de priora-: la imagen suple a la priora y la Virgen real a la propia imagen (descensión que dura por espacio de una salve), en señal de que las monjas habían acertado en la elección de priora.

19 "Entrar por la manga", "acogerse al manto" y "ser hijo del manto" son expresiones que trae Correas en su Vocabulario aludiendo al antiguo rito de prohijar. Acogidas al manto de Nuestra Señora se representaron las órdenes religiosas (variante iconográfica conocida como Virgen de la Misericordia) preservadas así del mal y amadrinadas por María: pinturas que probablemente conocía Teresa.

${ }^{20}$ El tema de la suplantación de la monja en sus obligaciones por Santa María se recoge en la Cantiga LV: "Esta é como Santa María serviú pola monia que se fora do moesteiro et lli criou o fillo que fezera alli andando [...] más de que a non achavan ménos, sse maravillavan". Igualmente en la Cantiga XCIIII: "esta é como Santa María serviu en logar de la monia que sse foi do moesteiro [...] mais ant'ela foi leixar chaves que tragía na cinta, ant'o altar da en que criya [...] leixo-vos est'en comenda, [...] quanto leixou aa Vírgen comendado en seu logar ela muy ben o guardou" Cantigas de Nuestra Señora. Sigo la edición facsimil de la publicación de la RAE [1889] en 1990. 
3. Teresa, becha una Quinta Angustia. Identificación con una iconografía concreta de culto

Estando la misma noche en maitines [Sevilla y octava de Todos los Santos] el mismo Señor, por visión intelectual, tan grande que casi parecía imaginaria se me puso en los brazos, a manera como se pinta la Quinta Angustia. Hízome temor harto esta visión, porque era muy patente y tan junta a mí, que me hizo pensar si era ilusión. Háseme quedado esta visión hasta ahora representada (Cuentas de Conciencia: 44, 4-6).

Quizá el deseo compasivo (de cum-patere) de Teresa la llevó a la ilusión de hacerse una con la co-redentora. Inconscientemente afloró también, creo, el natural instinto de maternidad ${ }^{21}$. Se ve la santa en el papel de la Quinta Angustia "como se pinta". Este retrato de dolorosa-madre que ella representa con mezcla de placer y dolor es corregido por el propio Cristo cuando le dice: "no pienses cuando ves a mi Madre que me tiene en los brazos, que gozava de aquellos contentos sin grave tormento -Desde que le dijo Simeón aquellas palabras" (Cuentas de Conciencia: 26,1). Mensaje realista que reconduce a Teresa

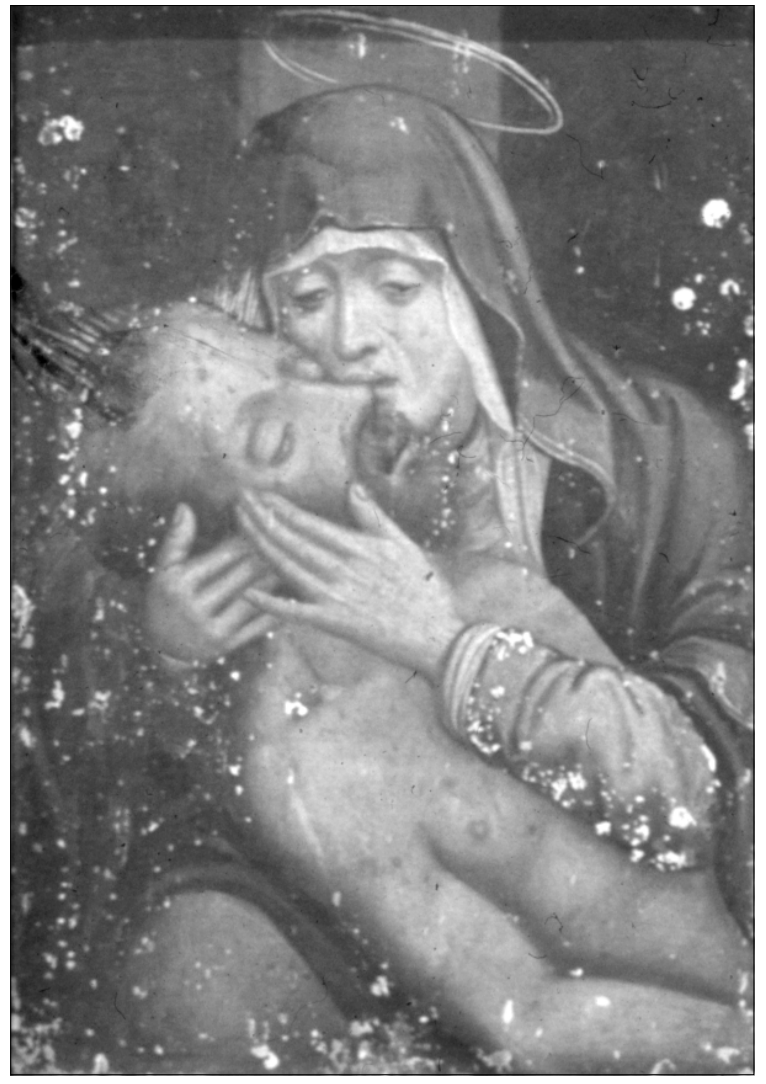

Figura 5: La Quinta Angustia. Monasterio del Zarzoso (Salamanca), siglo XVII, óleo sobre cobre (Foto A. Cea).

${ }^{21}$ La evidente desproporción anatómica que en la iconografía de la Piedad suele darse entre la figura de la madre y la del cuerpo muerto de Cristo sobre su regazo, ostensiblemente pequeño (salvo en las escuelas realistas), responde a una firme intencionalidad de ensoñación mística. Se trata del nuevo parto de la Redención que hace a María coredentora: cuando en el pesebre lo presentía muerto y ahora lo cree dormido. 
hacia la correcta interpretación del icono, que debe leerse en clave de dolor y no de gozo: cuna/cruz; rosas/hiel; aparente gozo/verdadero tormento. Afirma la santa la indelebilidad en su vida de esta impresión figurada.

\section{El abrazo a una imagen de Nuestra Señora como signo de asilo y acogimiento a sagrado}

So capa de paseo por el campo, una hermana de Don Antonio de Padilla, en edad de casar, se acoge al monasterio de Carmelitas de Valladolid:

Y en abriendo, entróse dentro y fue a abrazar con Nuestra Señora, llorando y rogando a la priora no la echase. Las voces de los criados eran grandes y los golpes que davan a la puerta. [...] Les dijo que por ninguna manera saldría, que lo fuesen a decir a su madre [sucedió el día de la Concepción y la Justicia la vino a sacar el de los Inocentes] (Fundaciones: 11, 5).

El gesto del abrazo de esta doncella con una imagen de la Virgen, probablemente en el zaguán del monasterio o en el locutorio significaba, o así lo quería ella, la ius de acogerse a sagrado y el derecho de asilo (de nuevo el rito de "ser hijo del manto") y una manera de ser tomada como propiedad del monasterio. Como no hay respuesta manifiesta en la imagen la doncella hace testiga del gesto a la priora para que lo haga valer.

\section{Las imágenes de San José y Santa María, porteros divinos del monasterio}

Refiere Teresa en el Libro de la Vida $(32,11)$ la directa intervención divina sobre la fundación de San José de Ávila: "que no se dejaría de hacer el monasterio y que se llamase San Josef y que a la una puerta nos guardaría él y Nuestra Señora la otra y que Cristo andaría con nosotras; y que sería una estrella que diese de sí gran resplandor ${ }^{22}$. Se resalta en primer lugar en este pasaje la importancia de las funciones defensivas del convento como castillo del alma y el negocio de rearmar bien sus entradas. Registro medieval comparativo, fruto quizá de sus antiguas lecturas caballerescas. Señala también la necesidad de la presencia de San José,

${ }^{22}$ La manifestación de estrellas (a parte del prototipo de la Epifanía) como premonición profética de éxito espiritual de una fundación que iluminaría con su resplandor una comarca parece un topos contemporáneo de la santa. Así había sucedido, por ejemplo, en el caso de los monasterios salmantinos de Peña de Francia, Nuestra Señora de Gracia y Batuecas, por boca de la profetisa Juana, conocida popularmente como "la moza santa de Sequeros", en el año 1424, diez antes de la fundación del de la Peña. (Según comenta Fray José de Santa Teresa, 1693). 
custodio del Niño Jesús y guardián de sus monasterios. Esta seguridad en sus 'palomares' como apeaderos del cielo parece anticipar la visión en ellos de la Jerusalén celestial. De paso, trueca el modelo iconográfico tradicional del San Pedro clavero por el de San José. La imagen opera aquí como detente y talismán, no sólo contra los peligros del alma, también de los corporales: "Al Señor Diego Ortiz [en Toledo] que suplico a su merced, no se descuide tanto de poner a mi señor San Josef a la puerta de la iglesia ${ }^{23}$. El mismo tema y necesidad iconográfica (supeditada a la de la calidad) se muestra en el caso de la fundación de Palencia, posponiendo la hechura y traza de San José hasta comprobar las novedades de taller de la prestigiosa escuela de Burgos, donde a la sazón se encontraban: "no digo más de que el San Josef no se haga ahora hasta que veamos acá lo que hay „24.

\section{El crucifijo prodigioso de Beas}

Estando un día en una pieza [...] llegó a leer en un crucifijo que allí estava el título que se pone sobre la cruz, y súpitamente en leyéndole la mudó toda el Señor. Ansí como leyó el título le pareció havía venido una luz a su alma [...] y con esta luz puso los ojos en el Señor que estava en la cruz corriendo sangre. Estando en esto, vino un ruido tan grande encima de la pieza que parecía toda se venía abajo [por enfado del demonio] (Fundaciones: 22, 5-8)25.

La pormenorizada descripción de este pasaje entra de lleno en la casuística (contemporánea y posterior a la santa) de los cristos que sudan sangre, hablan con sus devotos e intercambian y cruzan con ellos señales y letreros ${ }^{26}$. Imágenes que en ese momento se despiertan a devoción y rebautizan sus primitivas advocaciones con las nuevas de la Luz, del Sudor, etc. La lectura del letrero o título de la cruz, el INRI (conocida en este tiempo no sólo entre adoctrinados hombres de letras, sino por cualquier cristiano) suele pasar en estos casos prodigiosos a convertirse en el titulum triumphalis medieval que proporcionaba las victorias: «HOC SIGNO TUETUR

${ }^{23}$ Carta 28, desde Alba de Tormes en 5 de febrero de 1571.

${ }^{24}$ Carta 363 B desde Burgos, en contraste de pareceres con el canónigo Don Jerónimo Reinoso, en Palencia.

25 Este hecho prodigioso le sucedió en 1575 a la monja Catalina Godinez, fundadora de ese monasterio de Beas.

${ }^{26}$ Un caso semejante al aquí descrito sucedió con el desde entonces conocido como "Cristo del Sudor" en la iglesia parroquial de la Alberca (Salamanca),el día 6 de septiembre de 1655. Ver en de los Hoyos, 1982: 102-108. El prodigio que narra Santa Teresa concuerda en lo fundamental con el texto de la llamada cruz de San Benito con la consiguiente leyenda: "Crux sit mihi lux, non draco sit mihi dux ...". 
PIUS, HOC SIGNO VINCITUR INIMICUS". Esta lectura ilumina (no queda claro si también físicamente) la hechura de la imagen que se representa sudando sangre o la comienza en ese momento a sudar. El estruendo que acompaña a la iluminación del Cristo -y del alma-, descubre la huida del demonio como enemigo y desvela, una vez más, la deuda con el mundo de lo caballeresco en la obra de Santa Teresa que, en gran medida, concibe la espiritualidad como una batalla entre la militia Dei y la militia diaboli, conceptos militarizados que retoma también Ignacio de Loyola con la fundación de su Compañía de Jesús.

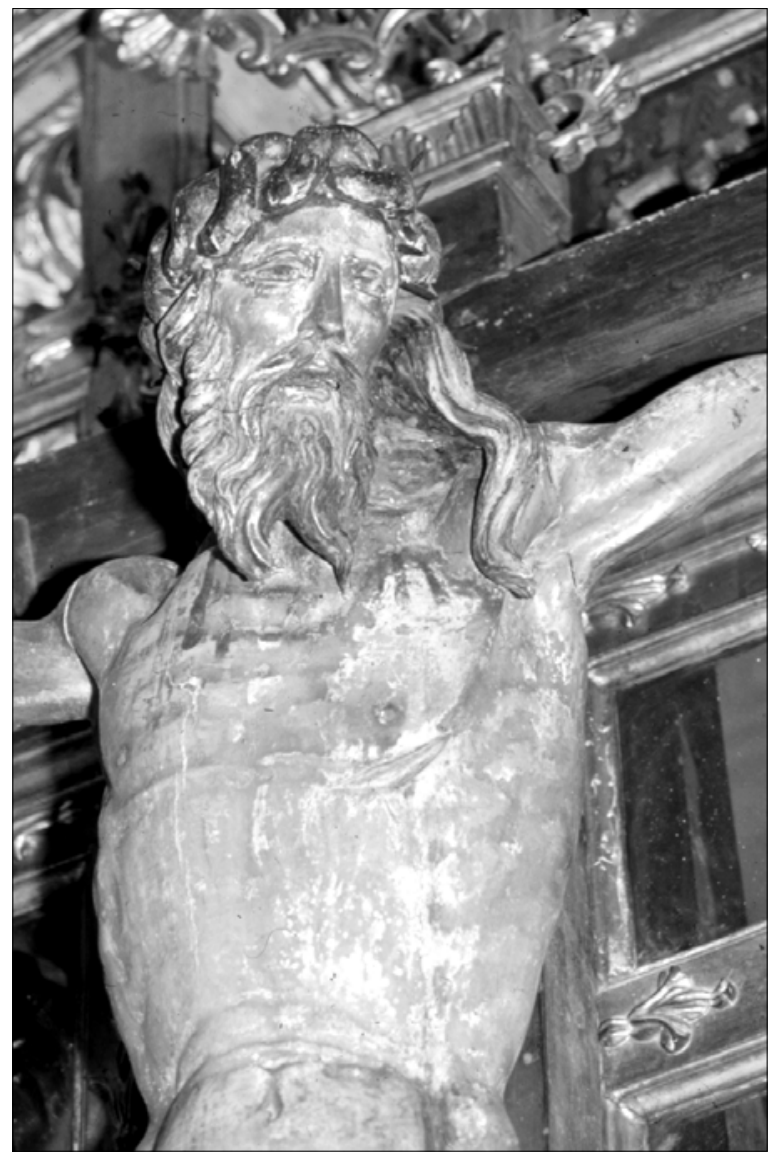

FIgURA 6: Crucifijo albercano "del Sudor", detalle, siglo XVI, escuela de Valladolid (Foto A. Cea).

\section{SANTUARIOS E IMÁGENES}

\section{Nuestra Señora de la Calle en Palencia}

Gracias a las detalladas impresiones en algunas cartas y en el Libro de las Fundaciones (id: 29,13; 29,17; 29, 22 y 23; 29,27 y 29,29) ${ }^{27}$ sobre el caso palentino de Nuestra Señora de la Calle conocemos hoy aspectos sociales, morales y festivos, desveladores de la religiosidad mariana de su tiempo. Familiarizados con descripciones literarias sobre santuarios en autores generalmente masculinos como Tirso o Cervantes, resultan particularmente

\footnotetext{
27 Cartas 343, 347-348, 361 y 376.
} 
valiosas las de una mujer desde su perspectiva de emprendedora y santa, que pasamos sólo a enunciar:

- Se trata de una ermita situada en lo mejor de la ciudad y que iba a convertirse temporalmente en la capilla de su propio monasterio carmelitano si deciden instalarse allí.

- Es lugar que define como "de grandísima devoción", con una difusión de ámbito local y comarcal.

- El santuario disfrutaba de dos misas diarias "y otras muchas que se dicen", y acostumbraba a tener la imagen vigilias nocturnas, causa de vicios al estar solitaria ${ }^{28}$.

- La imagen de la Virgen no gozaba del decoro necesario y estaba puesta "muy indecentemente" 29 .

Para la toma de posesión del monasterio de carmelitas (momento que la santa describe precisamente), la Virgen les salió al encuentro: —que la mesma imagen vino también por nosotras»-, escenificando la bienvenida a la comunidad de monjas como si de persona viva se tratara.

\section{Nuestra Señora del Socorro de Cardona o el caso de la beata Catalina}

Este beaterio a las afueras de Villanueva de la Jara, cercano a la ermita de Santa Ana, estuvo habitado por la beata Catalina de Cardona. Emparedada durante ocho años en una cueva y con fama de santa viajó hasta Alcalá de Henares en busca del Padre Piña como ermitaño. Teresa describe ese espacio, luego monasterio de carmelitas, como cosa curiosa de ver y desierto sabroso, igual que en el florido tiempo de los eremitas, reinterpretando la cueva de Elías.

La beata de Cardona, rezando a un crucifijo, vió una capa blanca en señal de que aquel lugar habría de ser de frailes carmelitas. Se erige la iglesia en el lugar de la primitiva cueva, construyendo para la beata en vida un sepulcro de bulto. A su muerte fue depositado su cuerpo hasta hacer mayor iglesia en una capilla de Nuestra Señora de la que la Cadorna era de-

${ }^{28}$ Las consecuencias y abusos morales de estas costumbres socio-religiosas, reiteradamente condenadas en los mandatos episcopales de Santa Visita, las recogió también Correas en su Vocabulario de refranes: "romería de cerca, mucho vino y poca cera" y comenta: "Porque llevan almuerzos y meriendas y más van a solazarse que con debida devoción". También trae: "ir romera y volver ramera".

${ }^{29}$ En los Libros parroquiales se dice de una iglesia, altar o imagen que está "con indecencia" cuando no recibe la atención de culto y ornato que le corresponde por falta de medios necesarios o por poca devoción y negligencia. 
vota, santuario que —en opinión de Teresa - estaba bien prevenido de ornamentos. Este pasaje de las Fundaciones (28,8; 28,11; 28,20; 28,24; 28,2728-29; 28,32-33 y 28,35), desde una perspectiva etnohistórica nos parece excepcional por la abudancia y calidad de materiales que la santa de Ávila se detiene en pormenorizar, seguramente impresionada por las carcaterísticas de aquel paraje convertido en nueva Tebaida: "pareciéndome estar en aquel florido tiempo de nuestros santos padres", refiriéndose a Elías, Hilarión, etc.

Subrayamos a manera de enunciados los temas de interés en este texto desde la Antropología Cultural y la Religiosidad:

- El crucifijo y la visión de la descensión del manto.

- El eremitorio y monasterio como espacio natural recreado y ampliado.

- El olor a santidad y el tema de las reliquias.

- La imago poenitentis y la descripción de la beata Cardona como mujer selvática.

\section{El Cristo de Burgos, devoción digna de ver}

Los dos pasajes en que Teresa de Ávila menciona el Cristo de Burgos son ejemplo del topos literario sobre la fama local, maravilla y, en este caso, curiosidad devota: "con este mal camino llegamos a Burgos [...] quiso nuestro Padre [Gracián] fuésemos lo primero a ver el santo Crucifijo para encomendarle el negocio". "Su paternidad no quiso que dejáramos de ver el Crucifijo de ese lugar [entonces en el convento de los agustinos del barrio de la Vega], y ansí dicen que antes que entremos se ha de ir allá" (Fundaciones: $31,18$ y carta 405$)^{30}$. Siguiendo el mandato de Gracián hace de este viaje fundacional también una romería, poniendo al Cristo como fiador de este negocio y en señal de buen augurio.

\section{La cruz de Caravaca como objeto piadoso de recuerdo y protección}

En la misma línea que la del apartado anterior y como recuerdo protector y de piedad comenta Teresa por carta desde Toledo a su amiga María de San José en el Carmelo de Sevilla: "Alberta [Ana de San Alberto, priora en el de Caravaca] ha escrito a Doña Luisa [de la Cerda] y enviádola una cruz ${ }^{31}$. Aunque no se expresa directamente, debe tratarse de la advocación local de Caravaca, cruz tan apreciada como detente contra rayos y centellas.

30 Aparte de los milagros que se atribuyen a este crucifijo, llama la atención la imagen por la curiosidad extravagante de su material -piel humana- que, según creencia, recubre esta figura. (Ver Alarcón 1990: 250-251).

31 Carta 153, en 7 de diciembre de 1576. 


\section{SANTA TERESA Y EL USO Y NECESIDAD DE LAS ESTAMPAS}

El Padre Hernando de Pantoja, prior de las Cuevas en la Cartuja de Sevilla, aparece como proveedor de estampas para la santa, siendo intermediaria la mencionada María de San José, priora de Sevilla. En posdata a esta monja desde Toledo le dice: «Si el padre prior [el tal Pantoja] le diese las estampas, no me tomen ninguna, que allá les dará cuantas quiera ‘2.

Sabemos por testamento de 1507 que la prensa de Maese Niculás, vecino de Triana, especializada en estampación de imágenes queda para los monjes de la Cartuja a condición de una misa diaria por su alma. De este taller pudieron ser las que con abundancia llegaban a la santa (Portús y Vega 1998: 29) 33 .

El deseo posesivo de acopiar estampas denuncia el fuerte interés de Teresa por este género. La carencia que demuestra durante su época toledana se sacia con creces durante su estancia en la floreciente Sevilla, antesala de dos continentes y bien abastecida de toda mercaduría. En primer lugar, los grabados se utilizaban, tanto para santificar las paredes de los conventos: portería, claustra, celdas, como devociones comunitarias y privadas. Además enriquecían e ilustraban los libros litúrgicos y se colaban como devociones personales en las estampas sueltas de misal. Otros grabados pequeños de pergamino y de papel eran recortados para embutir en relicarios de altar o guarnecer los de los rosarios o los que se llevaban sobre el pecho (Portús 1990: 225-246). Se reutilizaban también en escaparates de monjas ('conventinos' y 'teatrinos') formando escenas de la religiosidad cotidiana, generalmente para regalar a parientes y bienhechores; obras conocidas como de "labor de monjas".

Veinte días después de la carta de arriba ${ }^{34}$ escribe a su hermano Lorenzo, residente en Ávila, con tres recomendaciones: que le envíe el arquilla con unos papeles que contenía. Que le mande su sello personal para lacrar, "que no puedo sufrir sellar con esta muerte [sic por calavera, el sello que ella tenía en Toledo] sino con quien querría que lo estuviese en mi corazón como en el de San Ignacio ${ }^{35}$. Creemos que alude al anagrama de

32 Carta 157, en 13 de diciembre de 1576. Por estos años la escuela alemana de grabadores, con Durero a la cabeza, iba decayendo en favor de los flamencos. (Ver Bonet y Cañete 1990. También Carrete Delgado y Vega 1981 y Navarrete 1998. Igualmente, Griffin 1991 y Hazañas 1945-1949).

$33 \mathrm{Al}$ prior de las Cuevas le había enviado una copia manuscrita de Camino de Perfección.

${ }^{34}$ Carta 16, de febrero de 1577 desde Toledo.

35 Los editores de las Obras Completas por donde cito los textos de la santa (Efrén de la Madre de Dios y Otto Steggink) en la nota 4 de la página 835 afirman, creo erró- 
Jesús ${ }^{36}$ representado como sol radiante, lema e icono de los jesuitas. Retoma aquí Teresa el ejemplo de la técnica de estampación relacionándola con la impresión del rostro de Cristo o de sus atributos y emblemas en el alma y en el corazón. También como técnica y efecto de la oración, o de un tipo de oración.

Por último, encarece a su sobrina Teresa, la preferida, "que reparta las imágines y no las que yo aparté para mí, y que dé algunas a sus hermanos». Hay pues en la mente de la monja estampas de quedarse - ya preseleccionadas - y otras para repartir ¿Conocía su sobrina las debilidades devocionales y gustos de su tía, o las tenía Teresa de antemano señaladas?

Seis meses más tarde, en carta a María de San José ${ }^{37}$, hablando del canje de mercancías (crucifijos toledanos por estampas de Sevilla) se extraña Teresa de que nada le comente sobre su calidad ni si la recibió, quejándose también por que no llegaron las estampas enviadas por la priora para "Doña Luisa" [de la Cerda]. Esto confirma, además, su uso entre la nobleza, quizá y sobre todo por lo que suponía de divulgación de modelos iconográficos novedosos sobre los más tradicionales, que se mantenían en sus colecciones de pintura. También la utilidad de la estampa como fineza de cumplimiento para con los benefactores. Sutilmente y a reglón seguido confirma la santa cómo el Padre Gracián «abrió el pliego y quedóse con las estampas" y cómo él y el Padre Heredia "estaban en contienda con ellas". Se percibe en este pasaje el interés por las estampas no sólo como cosa de monjas, también entre clérigos ilustrados que se las hurtan a Teresa: "dos vi y son lindas" (no dice cuáles). Parece pues que el suministro de estampas que con diversos fines le era enviado con cierta regularidad por vía de su subalterna y confidente sevillana, María de San José, no siempre llegaba a su destino.

De nuevo seis meses después, ya desde Ávila ${ }^{38}$, vuelve con la de Sevilla sobre el tema de las estampas (en postdata de puño de su secretaria Isabel de San Pablo):

Ahora se me acuerda he oido decir que hay ahí unas imágines de papel grandes y muy buenas, que Julián Dávila las loava; díceme nuestra madre que pida a

neamente, que ella se refiere a San Ignacio de Antioquía. Es obvio, en cambio, el lema del IHS en sol que luce como atributo propio sobre su pecho y de su Compañía el de Loyola.

${ }^{36}$ Había en su tiempo una oración al nombre de Jesús de la que era devota una monja suya, la hermana Estefanía Samaniego. Ver Desafio espiritual 26.

37 Carta 198 desde Toledo, con fecha 11 de julio del 77.

38 Carta 224, con fecha 28 de marzo de 1578. 
vuestra reverencia un San Pablo $^{39}$ destas [...] que sea muy lindo [...]; ha de ser cosa que me buelgue en mirarle [las cursivas son mías].

Se verbaliza y contrasta la calidad, tamaño y temática de los grabados y aunque tiene criterios propios y debilidades personales se deja guiar por el buen juicio de Dávila. No busca sólo en las estampas la finalidad exclusivamente religiosa de ser movida a devoción por ellas, también sentir deleite y holganza: placer estético y visual. En una postdata desde Ávila ${ }^{40}$ agradece a Gracián "el regalo de la imagen". Emplea aquí el término imagen en sentido general y refiriéndose a las estampas ¿Se trata de una de las que le retuvo un año antes, quizá la del San Pablo?

Casi dos años más tarde, estando entonces en Malagón, da cuenta de haber recibido, por fin, el San Pablo. No sólo lo encontró muy lindo sino que utilizando su natural vis cómica y su agudo sentido comparativo comenta a María de San José el parecido que le había encontrado "en chiquito" con la hermana 'Gabriela' [Leonora de San Gabriel], monja en el de Sevilla, y manda a decir que se lo comenten a la propia. El parecido cómico fue razón añadida por lo que "me cayó en gusto". Se queja Teresa de la utilización rutinaria de las estampas como amuleto, llegando a perder su verdadero sentido: "No para traerle en el seno [el rostro de Cristo] y nunca le mirar" (Camino de Perfección: 43,2). En la mente de la santa está la verdadera finalidad de las estampas como recordatorio del Amado "para muchas veces hablar con él.. Esto es necesario de manera especial cuando la imagen de Cristo no está muy esculpida en el interior y hay que servirse del retrato exterior. Es pues Teresa partidaria - y necesitada- de la costumbre de portar estampas sobre el pecho, como de uso íntimo y personal función protectora: "acostumbrarse a enamorarse mucho de su sagrada Humanidad, traerle consigo y hablar con él [...]. Quisiera yo siempre traer delante de los ojos su retrato e imagen, ya que no podía traerle tan esculpido en mi alma como yo quisiera" (Libro de la Vida: 12,2 y 22, 4) (1. $^{4}$.

La afición a las estampas le viene, creo, también por asociación infantil y esto se advierte claramente en el pasaje sobre la Samaritana; no sabemos

39 A menudo se identifica con San Pablo y la Magdalena como arrepentidos en los que espejarse: "Si no mirad un San Pablo o una Magdalena: en tres días él no comenzó a entenderse que estaba enfermo de amor, y la Magdalena en uno". Camino de Perfección 69, 3.

${ }^{40}$ Carta 244, de 19 de agosto de 1578.

${ }^{41}$ Lope de Vega en el auto Nuestro Bien pone en boca de San José refiriéndose al Niño Jesús esa costumbre de la época cuando dice: "siempre le traigo estampado en mi pecho, y si pudiera / en el alma le trujera / como un papel retratado". Alonso de Bonilla en Peregrinos Pensamientos compara en un soneto la impresión de los estigmas de San Francisco con los procesos del grabado y la impresión (Portús 1990: 228). 
si el recuerdo refiere a una estampa de pared o estaba en un libro de oraciones. Hemos de subrayar aquí, además de la función de la imagen, la del texto o pie que la completa e interpreta: "Desde muy niña lo era [aficionada al episodio evangélico de la Samaritanal y la tenía debujada a donde estava siempre con este letrero, cuando el Señor llegó al pozo: “Domine da miqui aguan" [sic] (Libro de la Vida: 30, 19) ${ }^{42}$.

\section{La impresión en el alma de la imago Christi}

La idea del sigillum Dei, indeleblemente impreso en el alma aparece en tres pasajes del Libro de la Vida $(7,6 ; 27,5$ y 37, 4) y relaciona este proceso con el de las estampas grabadas. El alma es buen material y estampa de calidad duradera para el certero retrato de Cristo:

Representóseme Cristo delante con mucho rigor [con precisión y nitidez], vile con los ojos del alma [...] y quedóme tan imprimido que á esto más de veinteseis años y me parece le tengo presente».[ ] "que quiere el Señor esté tan esculpido en el entendimiento que no se puede dudar". [ ] "De ver a Cristo me quedó imprimido su grandíssima hermosura y la tengo hoy día, [la cursiva es mía].

De hecho, la santa está alabando la perdurabilidad y técnica del estampado. Necesita de la imagen material para encontrarse con la humanidad divina en la oración. Sólo cuando se tiene acceso a las moradas séptimas resultan inútiles las imágenes, música y sermones, porque ya 'la mariposilla' se ha abrasado en Dios (Moradas del Castillo interior. 2, 6). En carta a Gracián ${ }^{43}$ y refiriéndose a las discordias del monasterio sevillano en julio de 1579 describe el alma como cordera sellada y "ganado de la Virgen" que hay que tener muy ordenado; parece dibujar la santa con claridad, anticipándose en dos siglos, la iconografía capuchina de la Divina Pastora.

Perdurabilidad y caducidad son dos términos que van emparejados al concepto de estampa. Es, además, la asequible imagen pobre, capaz de provocar más devoción que una rica y "curiosa", muy acorde con la extrema pobreza carmelitana:

Nunca se me olvidó una cruz pequeña de palo que tenía para el agua bendita [el convento de frailes en Duruelo], que tenía en ella pegada una imagen de papel con un Cristo, que parecía ponía más devoción que si fuera de cosa muy bien labrada (Fundaciones: 14,6).

42 Utiliza aquí la santa el término letrero como pie y complemento escrito, aclaratorio de la imagen y con el mismo sentido que aparece en su composición: Muero porque no muero.

43 Carta 285, de Valladolid a Alcalá. 
Se confirma aquí la estampa como complemento de la señal de la cruz y del agua bendita, implacables armas contra el demonio en el culto público.

\section{LA ICONOGRAFÍA DEL DIABLO}

Son muy abundantes las ocasiones, a veces en cada página escrita por la santa cuando no es transportada a las alturas de la mística, en que aparece su cosmovisión regida por los dos signos de la balanza: el principium boni (con la visión de Dios) y el principium mali (con la presencia turbadora del diablo, solo o en manada). Los textos de Teresa perfilan el retrato del maligno y sus mañas con las siguientes variantes: Las pocas veces en que toma forma se percibe con muy abominable figura, especialmente su boca, de la que salen llamas sin sombra. Es "negrillo", con cuernos y envuelto en un fuerte olor azufrado. Sus oficios y actitudes con Dios y con el Hombre presentan en síntesis esta panoplia de posibilidades:

- En contiendas con ángeles;

- Como pintor del rostro divino, hecho un falso San Lucas;

- Como iconoclasta en el mundo de los herejes;

- Hacedor de ardides y trampas contra el alma;

- Como carroñero sacando el cuerpo en pecado de una fosa y arrastrándolo con garfios al infierno;

- Al lado izquierdo de la santa con idas y venidas tentadoras;

- Alrededor de Teresa cercándola ["tanquam leo rugiens, circuit quaerens quem devoret.].

- Impidiendo los rezos de la de Ávila y sentándose sobre su libro de horas para que no salgan con ellos las ánimas del purgartorio;

- Huyendo y repitiendo el acoso del que Teresa se defiende con agua bendita y con la cruz;

- Vencido y enojado, rompiendo el pacto escrito de la compra del alma.

Las principales armas con que se defiende la monja son: la cruz (con la cruz se va pero vuelve); el agua bendita (no vuelve y es más eficaz, con la que se mata el fuego); haciéndole la higa; santiguándose; invocando a los santos guardianes.

\section{CASUÍSTICA ICONOGRÁFICA RELACIONADA CON EL DIABLO}

\section{El clérigo que daba la comunión en pecado}

En dos ocasiones (Libro de la Vida: 38, 22-23) ve Teresa dos demonios rodeando con los cuernos la garganta de un clérigo, al mismo tiempo que 
la majestad de Dios en la hostia los mantenía amedrentados. Ellos por su parte intentaban huir sin poder alejarse de la terribilidad divina. Por un lado, no sueltan la presa, por otro se sienten sometidos, tal y como suelen representarse en la iconografía de la apoteosis del nombre de Jesús.

\section{Mientras Teresa reza se le presenta el diablo por la izquierda}

En otras dos ocasiones (Id: 31,2$)$ ve al demonio con espantable figura, especialmente la boca, y en su cuerpo una gran llama sin sombra, toda clara $^{44}$. Teresa se santigua y el diablo desaparece pero torna luego. La segunda vez le echa agua bendita que tenía a mano a la parte izquierda y no vuelve más (Libro de la Vida: 31, 4). Esta iconografía del fuego sin sombra se contrapone a la de la Tota Pulchra con el resplandor ${ }^{45}$. Nos preguntamos si el agua como medicina y contraveneno lo guardaba la santa en una poma de perfumes o en un frasquillo.

\section{Teresa tentada por el diablo negrillo}

Esta visión, que la santa no sabe interpretar, es en realidad la fórmula que Dios le plantea para llegar al conocimiento del mal: "quiso el Señor entendiese cómo era el diablo" (Libro de la Vida: 31, 4 y 5). Ella percibe que está "cabe mín pero no acierta a saber de qué lado. Su figura se manifiesta "Como muy abominable negrillo" regañando y desesperado por las dificultades de enfrentarse con Teresa (más aquí como trasgo que como verdadero maligno). El cebo que le pone el diablo y el remedio que busca en el agua bendita la de Ávila van acompañados de unos ingredientes que tiñen de comicidad este curioso pasaje. Se vale el diablo ante la santa de que, al estar en oración pública y para no amedrentar a las monjas, no teniendo ella a mano el agua no iba a pedirles auxilio. Utiliza como defensa la cruz pero al final se ve obligada, ya que no cejaba el demonio, a demandar el agua porque temía se riesen. «Dije: si no se riessen pediría agua

${ }^{44}$ Es evidente en este pasaje la presencia del motivo literario del cuerpo sin sombra, tema que da lugar a diversos subtipos: los demonios maldicen con quitar la sombra; persona que no tiene sombra muere; el diablo se queda con la sombra en lugar de con el hombre; el diablo coge la sombra al granjero. Creo que el texto se ajusta más al tipo E743: persona sin sombra y, sobre todo al 755 y al 325* que aparece en España: espiritu maldito no tiene sombra. (Ver Aarne-Thompson 1995: 63, 155).

45 Se entiende en iconografía por resplandor el cerco de rayos (firmes o flameados), generalmente de plata que a manera de aura rodea la silueta de la Virgen como Inmaculada, manifestando así su santidad y gracia. 
bendita". Se define el demonio como enfermedad, y el agua como remedio y medicina: "y se me quitó todo mal". Subyace también, dentro de la práctica tradicional cristiana del alma, la selectividad de estrategias defensivas, prevaleciendo de hecho la virtud del agua sobre la de la propia cruz. Este pasaje y exemplum obliga a preguntarnos cómo puede plantearse asunto tan grave en envoltorio tan jocoso. No acertamos a desvelar si la presencia de la risa es aquí producto de la inconsciencia conventual en un contexto e intramundo infantilizado u obedece más bien a causas de familiaridad cotidiana con el diablo en la biografía de la santa.

\section{La tentación azufrada}

En esta brevísima descripción ( $I d: 31,6$ ), de apenas tres renglones, omite la santa el cómo, el cuándo y el dónde y se ve necesitada de pedir el remedio del agua bendita a las monjas presentes, con ello vence a varios demonios que, al huir, dejan un rastro de azufre sólo percibido por las monjas $^{46}$.

\section{Contienda entre ángeles y demonios}

Estando un día de la Trinidad en arrobamiento en el coro, vió la santa "una gran contienda de demonios contra ángeles" (Libro de la Vida: 31, 11). Es admirable la naturalidad con que describe este escueto pasaje como si se tratara sin más de una algarabía urbana de su época entre mozos de bandos enfrentados. Ella, que no acertaba a despegarse en la oración de las imágenes por más que en este caso la visión fuera merced de Dios y no ahinco personal de perfección, posiblemente hablara por boca de recuerdo o por la presencia de una pintura cercana sobre el Juicio Final donde las dos milicias, celeste e infernal, se disputan las almas.

\section{La santa cercada}

Entre las tentaciones visionarias con que es probada Teresa es frecuente la del acorralamiento por multitud de demonios "en derredor mio", del que ella se defiende también con una cerca, pero de luz $(I d: 31,12)$. Vuelve pues a sonar el tema del tentador como león rugiente rodeando al alma para devorarla, en este caso demonios en comparsa como danzadores me-

${ }^{46}$ El azufre es a la presencia del diablo como los rayos celestes y el olor a rosas y suavidad a las apariciones divinas. 
dievales de la muerte del alma ¿Ese anillo de luz inexpugnable era la metáfora de algún remedio circular en fórmula de oración, de agua bendita o de otro material protector no desvelado?

\section{El demonio estorbador sobre el libro de horas}

Estando en un oratorio, haviendo rezado un nocturno y diciendo unas oraciones muy devotas — que está al fin de él— que tenemos en nuestro rezado, se me puso sobre el libro, para que no acabase la oración; yo me santigüé y fuese. Tornando a comenzar tornóse; creo fueron tres veces las que la comencé y hasta que eché agua bendita no pude acabar. Vi que salían algunas almas del Purgatorio en el instante, que devía faltarles poco, y pensé si pretendía estorbar esto (Ibid: 31,10$)^{4}$.

En esta ocasión el diablo, parece, sería necesariamente pequeño y ligero presentándose como un contrafactum iconográfico del San Antonio de Padua, que sostiene en una mano, a manera de atributo, un Niño Jesús posado en un breviario.

Varias conclusiones se pueden espigar de este gracioso texto en relación con lo que hoy suele denominarse religiosidad popular:

- En primer lugar, se perciben características propias en el ritual oracional de cada orden religiosa.

- De nuevo aparecen los remedios más socorridos para ahuyentar al diablo: la señal de la cruz y el agua bendita.

- Es importante la manifestación, por boca de una mística, de la clasificación y distintos niveles de poder en las oraciones. La que ella estaba rezando es calificada como "muy devota". Como consecuencia de la anterior está la especialización en el rezo, en este caso para remedio de las ánimas del Purgatorio.

- No falta el topos de las tres veces. Ella le ahuyenta tres veces y el vuelve otras tantas, a lo que se suma el poder de ese número má$\operatorname{gico}^{48}$.

${ }^{47}$ Por nocturno se entiende una de las tres partes en que se divide el rezo o canto de maitines.

48 Oí contar de niño en Llanes (Asturias) de boca del protagonista (Felipón el de Soberrón) cómo se le presentó el demonio una noche cerrada de invierno en las inmediaciones de la ermita de Santa Marina en Parres. Parece como que el diablo, sometido a los pies de la mártir orensana, soltándose le salió al encuentro y le impedía el paso en figura de imponente toro. Dos veces intentó pasar y otras tantas se opuso el diablo hasta que a la tercera desapareció en medio de un horrible estruendo y humareda. Nunca más volvió a pasar por allí Felipón. 
- La importancia de la oración como poder comunicante dentro de lo que en la doctrina de la Iglesia se conoce por cuerpo místico tiene en la iconografía del Purgatorio, especialmente la de carácter más popular, una expansión y variaciones múltiples y muy representadas por la eclosión, en esta época, de las cofradías de Ánimas. En atinada percepción afirma en este pasaje la santa que pocas veces ha visto al diablo tomando forma y muchas sin ella, "Como la visión que, sin forma, se ve claro está allíw.

\section{Novenas y abogados contra el diablo}

Para verse libre de las insidias del maligno utiliza Teresa todos los recursos espirituales a su alcance y que, dentro de la piedad tradicional, consideraba válidos la Iglesia, dibujados con perfección en el siguiente pasaje como retrato del rezador por oficio y, en ese sentido, hecha una Celesti$\mathrm{na}^{49}$ : "Tomava santos devotos porque me librasen del demonio, andava novenas, encomendávame a San Hilarión, a San Miguel Ángel, con quien por esto tomé nuevamente devoción, y otros muchos santos importunava mos-

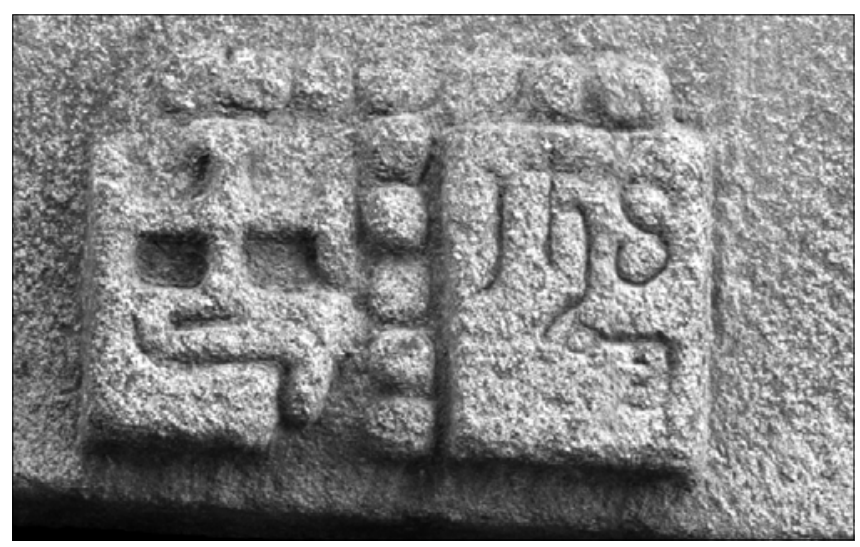

FIgURA 7: La cruz y el Nombre de Jesús sometiendo al demonio en figura de serpiente. Relieve en una toza de San Martín del Castañar (Salamanca), ss. XV-XVI (Foto A. Cea). trase el Señor la verdad" (Libro de la Vida: 27,1).

Se acoge primeramente a la devoción de San Hilarión cuya vida en el Flos Sanctorum (con la que sin duda ella estaba familiarizada) se pinta como un constante combatidor del demonio y protagonista de

49 Este pasaje recuerda muy de cerca, entre otros de La Celestina, el del auto I, donde dice: "Assaz era amiga de estaciones, procesiones, missas del gallo, missas del alba y otras secretas devociones". Cito por la ed. de Peter E. Russel, 1993, p.242. También parece emparentado el texto con otro del Lazarillo de Tormes (I, 14-15) cuando enumera su retahíla de oraciones: "Ciento y tantas oraciones sabía de coro. Decía saber oraciones para muchos y diversos efectos: para mujeres que no parían; para las que estaban de parto; para las que eran malcasadas, que sus maridos las quisieran bien". Vid. Cea y Álvarez. 1984: 49-50. 
múltiples hazañas, casi de carácter maravilloso. Estuvo en vida condenado a no poder ocultarse de sus devotos rogadores de milagros.

En segundo lugar, menciona Teresa la protección de San Miguel, devoción personal que ella califica de retomada (sería interesante conocer porqué la había dejado dormida). Es obvia la devoción al arcángel a poco que se siga su iconografía de capitán de las milicias celestiales contra el diablo. También podría haber invocado la protección de otros santos que muestran como atributo el demonio sometido, con mucha ascendencia en la religiosidad popular; es el caso de los santos Bartolomé, Antonio Abad, Marina y Margarita. Hasta cierto punto choca en una vida espiritual de la talla de la de Ávila este nivel de oración tan bajo y primario, importunando a los santos con machaconas peticiones, y no el de la oración como sagrado coloquio, tantas veces alcanzado en los grados más subidos de su éxtasis. Contra la interpretación habitual en la iconografía, Teresa ve a veces a Dios al lado izquierdo, cuando siempre la siniestra se toma como la parte del diablo ¿Se trata de una ubicación dislocada y en referencia al espectador que mira el cuadro? En su particular lucha, Dios le da como valedores, señores y guardianes a San Pedro y San Pablo que cuidarán de la seguridad de su castillo interior. San Pedro se representa como clavero del cielo y a veces en el cancionero popular como padrino de bodas con Nuestra Señora. San Pablo aparece como caballero romano con libro y espada (en esto gemelo a la figura de Santa Catalina), relacionado con el Amadís; residuo quizá de la cultura de su siglo y de las lecturas caballerescas de Teresa. El afecto y devoción que siente por San Pedro parece relacionado con el sentido de culpa y el deseo de mortificación de la carmelita: "que tenía más mando San Pedro con ser pecador, que San Bartolomé, que era hijo de rey". "Gusto yo mucho de San Pedro cuando iba huyendo de la cárcel y le apareció Nuestro Señor, y le dijo que iba a Roma a ser crucificado otra vez" (Camino de Perfección: 45, 2 y Moradas Séptimas: 4, 5). Utiliza la santa como remedio contra el diablo tres tipos de cruz: En primer lugar la higa, lo que le lleva a recordar las de los sayones a Cristo en su Pasión con las demás injurias y tormentos. La higa en la cultura popular, síntesis de paganismo y cristianismo, se asocia a la cruz que se forma con los dedos índice, pulgar y corazón — generalmente de la mano derecha- para la defensa contra el mal. En segundo lugar y como remedio, la señal de la cruz. Por último, la cruz que suele llevar en la mano con la que se enfrenta al diablo. Con ella podría disimular mejor ante las de su convento las peleas con el diablo.

En una ocasión nos dice que echó mano de la cruz de un rosario, pasaje que da lugar al sototexto conocido como la "cruz de piedras preciosas" (Libro de la Vida: 29, 7). En esa ocasión, teniendo la cruz en la mano se encuentra con la mano de Dios lo que origina una secuencia que re- 
cuerda la franciscana de los estigmas. Esa cruz se torna de cuatro grandes piedras preciosas, más las cinco llagas "de muy linda hechura", riqueza que sólo ella percibía: "más no la vía nadie sino yo". De nuevo prevalece la medieval imagen del signum triumphalis y el latente recuerdo iconográfico de las cruces de obra angélica con ricas labores de filigrana y pedrería (como las ovetenses de la Victoria y de los Ángeles) que fueron estandarte victorioso de los reyes cristianos, y con ellas el lema: HOC SIGNO VINCITUR INIMICUS como si arrastrara un préstamo icónico medieval clásico.

\section{Los demonios desenterradores o el caso del muerto sin confensión}

En oposición al demonio y demonios tentadores de Teresa están los demonios carroñeros y obreros que desarrollan su papel de la siguiente manera (Libro de la Vida: 38, 24 y 25):

- Estando amortajando el cuerpo de un difunto sin confesión ve (sólo ella) cómo muchos demonios juegan con el cuerpo con grandes garfios.

- Durante el oficio de difuntos desaparecen en las honras por su alma.

- De nuevo y mientras el enterrador echa el cuerpo en la fosa ve tal multitud de demonios para tomarlo que queda la santa espantada. Parece que hubiera comunicación desde el suelo de la sepultura con el infierno. En esta macabra pintura de la muerte hay una doble perspectiva: la de los amortajadores, clérigos y asistentes o caterva — ciegos a lo que está sucediendo-, y la visión que percibe Teresa. Curiosamente no se habla de tomar el alma, ni se describen los demonios, ni existe una confrontación entre un capitán y un santo o advocación que se interponga.

\section{El diablo como tramoyista, pintor e iconoclasta}

Entre la prolífica panoplia de retratos sobre el diablo, muestra ahora la santa la presencia sutil del tentador bajo el papel de artista y creador con una personalidad bífida. Juega el demonio a parecer bueno entre los católicos, hecho un San Lucas y creador de imágenes de calidad para el culto. Con los luteranos, en cambio, se manifiesta ferviente iconoclasta. Así el trampantojo convierte al demonio en dador o quitador de imágenes haciendo pasar por buenas sus malas obras según los intereses de cada grupo cristiano. De paso, deja plasmado la de Ávila en estos textos su propio criterio sobre la calidad y función de las imágenes. Dice en las Moradas Primeras: "y como la pobre alma no lo entiende [la legión de demonios que la 
impide acceder al castillo], por mil maneras nos hace trampantojos" $(2,12)$. En las Moradas Sextas y en las Fundaciones (9, 13 y 8, 3) desarrolla los siguientes argumentos que sintetizamos a continuación:

- El demonio es un gran pintor y en ocasiones muestra, muy a lo vivo, la imagen del Señor para que adoremos su obra y caigamos en la trampa.

- No hay que hacer higas a esta visión ni cruces aunque venga del diablo, porque la imagen de Dios es buena, venga de quien venga: "siempre se tenga respeto a donde viéremos un crucifijo u cualquier retrato de nuestro Emperador".

- El diablo hace una buen obra pintando esta imagen tan a lo vivo que se imprima en nuestro corazón.

- Cuando vemos una imagen de mucha calidad no importa que sea obra de un mal hombre y aunque un pintor sea muy torpe no por ello se ha de dejar de reverenciar la imagen que realiza.

- El bien o el mal no está en la visión, sino en quien la ve.

En Cuentas de conciencia (63) y respecto a la labor iconoclasta del diablo afirma: "que lo que el demonio hacía en los luteranos era quitarles todos los medios para más despertar, y ansí ivan perdidos". Parece querer confirmar Teresa, dada su personal dependencia de las imágenes, que no es posible llegar a Dios sin ellas y por tanto a la salvación del alma.

\section{El pacto roto}

Cuenta en el Libro de la Vida (39, 4) cómo "estando un día en oración [pidiendo por alguien apartado de Dios] vi un demonio cabe mí que hizo unos papeles que tenía en la mano pedazos con mucho enojo". Por intercesión de la santa el pecador se arrepiente en confesión anulando así el pacto firmado con el diablo. Este pasaje enlaza directamente con el tema folclórico del demonio burlado y algunas variantes de las doce palabritas ${ }^{50}$.

Para concluir, recordaré una de las estrofas del Muero porque no muero que compuso la santa. En ella nos deja de propia mano la esencia figurada de sí misma, su icono e imagen en autorretrato:

Vivo ya fuera de mí

después que muero de amor

50 (Ver Espinosa hijo 1998: 131-134). En la versión del labrador caritativo recogimos el trato del mayordomo del Cristo que entrega su alma al diablo a cambio del dinero para celebrar la fiesta, si el día que expire el plazo no sabe las doce palabritas (en Miranda del Castañar a Adela Novoa de 79 años, en octubre de 1973). 


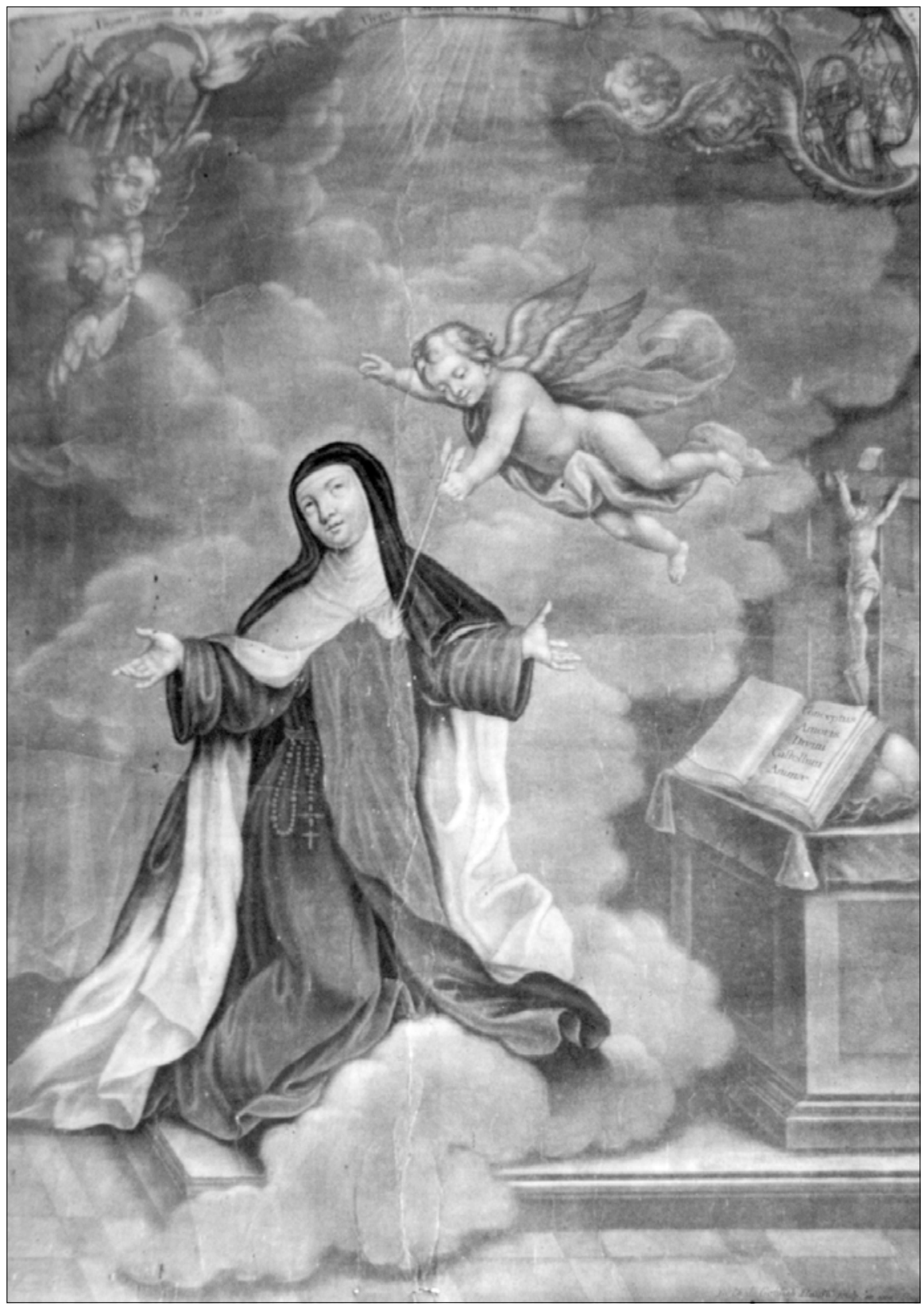

FIgURA 8: Transverberación de Santa Teresa. Grabado alemán del siglo XVIII, punta dulce (col. part., foto J. M. Castaño). 
porque vivo en el Señor
que me quiso para sí.
Cuando el corazón le di
puso en mi este letrero:
Que muero porque no muero.

Expresa prodigiosamente Teresa en esta cancioncilla el éxtasis y definitiva salida y la entrada en el Señor. Parece que queda su cuerpo como mera figura de barro, abandonada en Dios que la modela. Los desposorios místicos entre Cristo y Teresa con sus ademanes y atributos son, a mi entender, préstamo directo que ella toma de los de Gertrudis la Magna ${ }^{51}$, iconografía a la que la de Ávila estaba sin duda acostumbrada por libros o pinturas. En nuestro caso y probablemente sin saberlo, está manifestando Teresa el modelo más ajustado de su propia iconografía (Prados 1997: 8192), cuando entrega el corazón a Cristo y él le coloca el letrero: Que muero porque no muero (quizá de manera tan certera, o más, que en el conocido y espléndido pasaje de la transverberación). Ese lema podría muy bien ocupar una cartela o arquitectura efímera de su tiempo y ser título para una Concertación o Desafío espiritual en los que, sabemos, ella participó y que tenían lugar en sus conventos. Letrero que pone pie a su retrato de bodas y, de paso, a un modelo de santidad para su época.

\section{BIBLIOGRAFÍA CITADA}

Aarne, ANTTi y STITH ThOmpson. 1995. Los tipos del cuento folklórico. Una clasificación

(Fernando Peñalosa, trad.). Helsinki: Academia Scientiarum Fennica.

AlARCón, CONCEPCIÓn. 1990. "La iconografía religiosa en el siglo XVIII", Revista de Dialectología y Tradiciones Populares XLV: 247-278.

Alfonso X El SABIO. 1990. Cantigas de Nuestra Señora, ed. de la RAE. Madrid: Caja Madrid.

Berceo, Gonzalo De. 1971. Obras Completas II. Los Milagros de Nuestra Señora, ed. B. Dutton. Madrid: Ediciones Castilla S.A.

Bonet, Antonio y Juan Carrete. 1990. Arte y devoción: Estampas de imágenes y retablos de los siglos XVII y XVIII en las iglesias madrileñas. Madrid: Calcografía Nacional. Carrete, Juan; Juan Delgado y Jesusa Vega. 1981. Cinco Siglos de imagen impresa. Madrid: Subdireción General de Museos.

CEA, ANTONIO. 1992. Religiosidad Popular. Imágenes vestideras. Zamora: Caja España.

- 1996. "Robada, prostituida, restituida y siempre virgen. El caso de Nuestra Señora de Madrid (Tradición oral y Tradición escrita)". Revista de Dialectología y Tradiciones Populares LI, 1: 57-127.

51 Muestra la monja benedictina su corazón habitado por un Niño Jesús con un letrero que dice: In corde Gertrudis invenietis me. 
- 2000. «Fiesta, función, regocijos: claves religiosas y lúdicas en la sociedad rural salmantina del siglo XVIII. La obra de quita y pon", en M. Torrione (ed.), España Festejante. El siglo XVIII. Málaga: Diputación de Málaga: 127-143.

- 2002. "La calle como teatro: las representaciones en la Sierra de Francia (Salamanca), siglos XVI al XX", en J. Álvarez Barrientos (ed.), Espacios de la comunicación literaria. Madrid: CSIC: 55-106.

Cea, Antonio y Johquín Álvarez Barrientos. 1984. Fuentes etnográficas en la Novela Picaresca I. Los Lazarillos. Madrid: CSIC.

CORREAs, GonZAlO. 1924. Vocabulario de Refranes y frases proverbiales, Madrid: Tipografía de la "Revista de Archivos, Bibliotecas y Museos".

De los Hoyos, Manuel M. 1982. La Alberca Monumento nacional. Salamanca: Diputación de Salamanca.

Espinosa, Aurelio M. hijo. 1988. Cuentos Populares de Castilla y León II, 2 vols. Madrid: CSIC.

GRIFFIN, C. 1991. Los Cromberger: la historia de una imprenta del siglo XVI en Sevilla y Méjico. Madrid: Ediciones Cultura.

HaZAÑas y LA RuA, J. 1945-1949. La imprenta en Sevilla. Noticias inéditas de sus impresores desde la introducción del arte tipográfico en esta ciudad hasta el siglo XIX. Sevilla.

Jular, CRISTINA. 1999. "El cuerpo y la religiosidad medieval. La estatua y el amor físico en la Plena Edad Media", Revista de Dialectología y Tradiciones Populares LIV, 1: 103128.

KRÜGER, FRITZ. 1960. El argentinismo "es de lindo". Madrid: CSIC.

La Celestina. Comedia o Tragicomedia de Calixto y Melibea. 1993. ed. Russel, P. Madrid: Clásicos Castalia.

NAVARrete, Benito. 1998. La pintura andaluza del siglo XVII y sus fuentes grabadas. Madrid: Fundación de Apoyo a la Historia del Arte Hispano.

ORTIZ, CARMEN. 2000. «Papeles para el pueblo. Hojas sueltas y otros impresos de consumo masivo en la España de finales del siglo XIX", en Luis Díaz (coord.), Palabras para el pueblo. I. Aproximación general a la Literatura de Cordel. Madrid: CSIC: 145190.

OtTe, EnRique et al. 1988. Cartas Privadas de emigrantes a Indias, 1540-1616. Sevilla: Consejería de Cultura y Junta de Andalucía.

PAmplona DE, G. 1970. Iconografía de la Santísima Trinidad en el arte medieval español. Madrid: CSIC.

PORTús, JAVIER. 1990. "Uso y función de la estampa suelta en los Siglos de Oro (testimonios literarios)", Revista de Dialectología y Tradiciones Populares XLV: 225-246.

Portús, JaVier y Jesusa Vega. 1998. La estampa religiosa en la España del Antiguo Régimen. Madrid: Fundación Universitaria.

Prados, J. M. 1997. "El arte en Santa Teresa", en VIII Jornadas de Arte. La mujer en el arte español. Madrid: CSIC: 81-92.

Santa Teresa De Jesús. 1974 transcrip. y ed. de E. de la Madre de Dios y O. Steggink, Obras completas. Madrid: BAC, $4^{\mathrm{a}}$. 